\title{
RESEARCH
}

Open Access

\section{Human decidua basalis mesenchymal stem/ stromal cells protect endothelial cell functions from oxidative stress induced by hydrogen peroxide and monocytes}

\author{
M. A. Alshabibi' , T. Khatlani², F. M. Abomaray ${ }^{3,4}$, A. S. AlAskar ${ }^{2,5,6}$, B. Kalionis ${ }^{7,8}$, S. A. Messaoudi ${ }^{9}$, R. Khanabdali, ${ }^{7,8}$,
} A. O. Alawad ${ }^{1}$ and M. H. Abumaree Ald $^{2}$ (D)

\begin{abstract}
Background: Human decidua basalis mesenchymal stem/multipotent stromal cells (DBMSCs) inhibit endothelial cell activation by inflammation induced by monocytes. This property makes them a promising candidate for cell-based therapy to treat inflammatory diseases, such as atherosclerosis. This study was performed to examine the ability of DBMSCs to protect endothelial cell functions from the damaging effects resulting from exposure to oxidatively stress environment induced by $\mathrm{H}_{2} \mathrm{O}_{2}$ and monocytes.

Methods: DBMSCs were co-cultured with endothelial cells isolated from human umbilical cord veins in the presence of $\mathrm{H}_{2} \mathrm{O}_{2}$ and monocytes, and various functions of endothelial cell were then determined. The effect of DBMSCs on monocyte adhesion to endothelial cells in the presence of $\mathrm{H}_{2} \mathrm{O}_{2}$ was also examined. In addition, the effect of DBMSCs on HUVEC gene expression under the influence of $\mathrm{H}_{2} \mathrm{O}_{2}$ was also determined.

Results: DBMSCs reversed the effect of $\mathrm{H}_{2} \mathrm{O}_{2}$ on endothelial cell functions. In addition, DBMSCs reduced monocyte adhesion to endothelial cells and also reduced the stimulatory effect of monocytes on endothelial cell proliferation in the presence of $\mathrm{H}_{2} \mathrm{O}_{2}$. Moreover, DBMSCs modified the expression of many genes mediating important endothelial cell functions. Finally, DBMSCs increased the activities of glutathione and thioredoxin reductases in $\mathrm{H}_{2} \mathrm{O}_{2}$-treated endothelial cells.
\end{abstract}

Conclusions: We conclude that DBMSCs have potential for therapeutic application in inflammatory diseases, such as atherosclerosis by protecting endothelial cells from oxidative stress damage. However, more studies are needed to elucidate this further.

Keywords: Placenta, Decidua basalis mesenchymal stem cells, Endothelial cells, $\mathrm{H}_{2} \mathrm{O}_{2}$, Proliferation, Adhesion, Migration, Monocytes

\footnotetext{
* Correspondence: mohamedabumaree@hotmail.com; abumareem@ksau-

hs.edu.sa

${ }^{2}$ Stem Cells and Regenerative Medicine Department, King Abdullah International Medical Research Center, King Abdulaziz Medical City, Ministry of National Guard Health Affairs, Mail Code 1515, P.O. Box 22490, Riyadh 11426, Saudi Arabia

${ }^{10}$ College of Science and Health Professions, King Saud Bin Abdulaziz University for Health Sciences, King Abdulaziz Medical City, Ministry of National Guard Health Affairs, Mail Code 3124, P.O. Box 3660, Riyadh 11481 Saudi Arabia

Full list of author information is available at the end of the article
}

(c) The Author(s). 2018 Open Access This article is distributed under the terms of the Creative Commons Attribution 4.0 International License (http://creativecommons.org/licenses/by/4.0/), which permits unrestricted use, distribution, and reproduction in any medium, provided you give appropriate credit to the original author(s) and the source, provide a link to the Creative Commons license, and indicate if changes were made. The Creative Commons Public Domain Dedication waiver (http://creativecommons.org/publicdomain/zero/1.0/) applies to the data made available in this article, unless otherwise stated. 


\section{Background}

Mesenchymal stem cells (MSCs) are adult multipotent stromal cells that can be isolated from many tissues, such as human placenta [1]. Recently, we isolated MSCs from the maternal decidua basalis tissue (DBMSCs) of human term placenta [2]. The tissue of decidua basalis is a main source of oxidative stress molecules, which are found in the maternal circulation due to pregnancy [3]. Therefore, DBMSCs in their niche (vascular microenvironment) are in direct contact with the maternal circulation, and therefore, they are exposed to high levels of inflammation and oxidative stress mediators [4]. In addition, we also isolated MSCs from the fetal tissue (chorionic villi) of the placenta [5]. These fetal chorionic MSCs are in direct contact with the fetal circulation and therefore exposed to lower levels of inflammation and oxidative stress molecules as compared to DBMSCs [5-7].

MSCs from placenta and other sources can differentiate into multiple cell lineages including adipocyte, osteoblast, and chondrocyte [1]. In addition, MSCs show low immunogenicity and anti-inflammatory properties [1]. Therefore, MSCs have been investigated as promising therapeutic agents in many inflammatory diseases, such as atherosclerosis [8].

Atherosclerosis is characterized by endothelial activation due to the accumulation of high amounts of low-density lipoprotein (LDL) and immune cells that lead to the production of high levels of oxidative stress mediators, such as hydrogen peroxide $\left(\mathrm{H}_{2} \mathrm{O}_{2}\right)[9,10]$.

$\mathrm{H}_{2} \mathrm{O}_{2}$ has several important effects on endothelial cell functions in physiological homeostasis and in inflammatory diseases $[9,10] . \mathrm{H}_{2} \mathrm{O}_{2}$ alters the functional activities of proteins that cause the generation of more toxic radicals (i.e., peroxynitrite $\left(\mathrm{ONOO}^{-}\right)$and hydroxyl $(\cdot \mathrm{OH})$ ), which induce oxidative damage in the cellular DNA and proteins $[9,10]$. In addition, $\mathrm{H}_{2} \mathrm{O}_{2}$ can rapidly inactivate nitric oxide (NO) and this causes endothelial cell damage $[9,10]$.

Endothelial cell damage is usually associated with phenotypic changes (i.e., increased expression of inflammatory molecules), dysfunctional activities [i.e., increased endothelial cell proliferation, adhesion, migration, permeability, angiogenesis (blood vessel formational)], and also enhanced endothelial cell interaction with immune cells (i.e., enhanced monocyte adhesion to the endothelium and their infiltration into the tissues); these events are the typical characteristics of atherosclerosis [11]. In atherosclerosis, an inflammatory response is initiated at the injury site of endothelium that increases the expression of adhesion molecules (i.e., VCAM-1), which activates the recruitment and adhesion of immune cells (i.e., monocytes) to the injured site of endothelium [11]. This interaction between monocytes and endothelial cells will loosen up the tight junction between endothelial cells that increases the permeability of endothelium and subsequently monocytes and LDL will pass through the intima, where LDL undergoes oxidation while monocytes differentiate into macrophages, which take up oxidized LDL [11]. This lipid laden macrophages are known as "foam cells", which eventually die by apoptosis, but the lipid content will accumulate in the intimal area leading to the formation of plaque [11].

Recently, we reported that DBMSCs can protect endothelial cells from activation by inflammation triggered by monocyte adhesion and increased endothelial cell proliferation [12]. These events are manifest in inflammatory diseases, such as atherosclerosis. These data make DBMSCs as a useful candidate to be employed in a therapeutic strategy for treating atherosclerosis. We performed this study to examine the ability of DBMSCs to protect endothelial cell functions from the damaging effects resulting from exposure to oxidatively stress environment induced by $\mathrm{H}_{2} \mathrm{O}_{2}$ and monocytes. We investigated the ability of DBMSCs to protect endothelial cell functions (adhesion, proliferation, and migration) from oxidative stress induced by $\mathrm{H}_{2} \mathrm{O}_{2}$. The effect of DBMSCs on the adhesion of monocytes to endothelial cells in oxidative stress environment was also examined. Finally, we investigated the effect of DBMSCs on endothelial cell expression of many genes under oxidative stress, and the mechanism underlying DBMSC protection of endothelial cells from oxidative stress was also determined. Our data suggest that DBMSCs have a protective effect on endothelial cells in oxidative stress environment and suggest that DBMSCs have the potential to treat inflammatory diseases, such as atherosclerosis by protecting endothelial cells from injury induced by oxidative stress and inflammatory cells. However, future studies are necessary to elucidate this further in vitro and in vivo.

\section{Methods \\ Ethics and collection of human placentae and umbilical cords}

The study was approved by the institutional review board (reference number IRBC/246/13) of KAIMRC (King Abdulla International Medical Research Centre, Saudi Arabia). Samples (placentae and umbilical cords of uncomplicated human pregnancies, 38-40 gestational weeks) were obtained and used immediately after signing consent forms. All clinical and experimental procedures were performed in compliance with KAIMRC research guidelines and regulations.

\section{Isolation and culture of DBMSCs}

MSCs were isolated from the decidua basalis (DBMSCs) of the maternal part of human term placenta as previously described by us [2]. Briefly, the 
decidual tissues were dissected and then digested using a sterile phosphate-buffered solution (PBS; $\mathrm{pH}$ 7.4) containing $0.3 \%$ collagenase type I (Life Technology, Grand Island, USA), 270 unit/mL DNase I (Life Technology), and antibiotics $(100 \mu \mathrm{g} / \mathrm{mL}$ streptomycin and $100 \mathrm{U} / \mathrm{mL}$ penicillin). After 1-h incubation at $37{ }^{\circ} \mathrm{C}$ in a water bath, the cell mixture was filtered through a $100-\mu \mathrm{m}$ nylon filter (Becton Dickinson, NJ, USA), and the red blood cells in the cell pellet were then removed as previously described [12]. Cells were then washed with sterile PBS and cultured in a complete DBMSC culture medium [DMEM-F12 medium containing 10\% MSCFBS (mesenchymal stem cell-certified fetal bovine serum, catalogue number 12-662-011, Life Technology), and antibiotics described above] and then incubated at $37^{\circ} \mathrm{C}$ in a humidified atmosphere containing $5 \% \mathrm{CO}_{2}$ and $95 \%$ air (a cell culture incubator). Prior to using DBMSCs in subsequent experiments, DBMSCs at passage 3 were characterized by flow cytometry using MSC and hematopoietic markers (Table 1) and then evaluated for differentiation into adipocytes, chondrocytes, and osteocytes as previously described by us [2]. DBMSCs (passage 3) of 30 placentae were used in this study.

\section{Isolation and culture of human umbilical vein endothelial cells (HUVEC)}

HUVEC were isolated from umbilical cord veins using our previously published method [12]. Following rinsing the cannulated umbilical veins with PBS for several times, veins were filled with a digestion PBS solution containing $6 \mathrm{mg} / \mathrm{ml}$ collagenase type II (catalogue number 17101-015, Life Technologies) and then incubated at $37{ }^{\circ} \mathrm{C}$ in a cell culture incubator. After 25 min, HUVEC were collected and then resuspended in a complete endothelial cell growth medium (catalogue number PCS-100-04. $1^{\mathrm{m}}$, ATCC, USA) and cultured at $37{ }^{\circ} \mathrm{C}$ in a cell culture incubator as previously described [12]. Prior to using HUVEC in subsequent experiments, they were characterized by flow cytometry using a CD31 endothelial cell marker ( $\mathrm{R}$ and $\mathrm{D}$ Systems, Abingdon, UK) as previously described [12]. HUVEC ( $>95 \%$ purity) from passages 3 to 5 of 30 umbilical cords were used in this study.
HUVEC proliferation in response to DBMSCs and $\mathrm{H}_{2} \mathrm{O}_{2}$ HUVEC $\left(5 \times 10^{3}\right)$ were seeded in wells of 96-well culture plates containing a complete endothelial cell growth medium and cultured at $37{ }^{\circ} \mathrm{C}$ in a cell culture incubator. Following $24 \mathrm{~h}$, adherent HUVEC were incubated with different concentrations $[1 \%, 5 \%$ and $25 \%(v / v)$ conditioned medium $(\mathrm{CM})$ harvested from DBMSC culture (CMDBMSC) diluted in a complete DBMSC growth medium] of CMDBMSC and different ratios of 1:1, 5:1, and 10:1 HUVEC to DBMSC. Cells were then cultured in a complete endothelial cell growth medium with or without $100 \mu \mathrm{M} \mathrm{H}_{2} \mathrm{O}_{2}$ for $72 \mathrm{~h}$ at $37{ }^{\circ} \mathrm{C}$ in a cell culture incubator.

HUVEC proliferation was then evaluated after each indicated culture time points $(24,48$, and 72 h) by a tetrazolium compound [3-(4,5-dimethylthiazol-2-yl)-5-(3-carboxymetho xyphenyl)-2-(4-sulfophenyl)-2H-tetrazolium, inner salt; MTS] kit (catalogue number G5421, CellTiter $96^{\circ}$ Aqueous Non-Radioactive Cell Proliferation Assay, Promega, Germany), as previously described [12]. CMDBMSC was produced as previously described [12]. Before adding DBMSCs to HUVEC culture, DBMSCs were treated with $25 \mu \mathrm{g} / \mathrm{ml}$ Mitomycin C to inhibit their proliferation as previously described [12]. The blank was cells incubated in MTS solution in a complete endothelial cell growth medium alone. Results were presented as means ( \pm standard errors). Each experiment was performed in triplicate and repeated with five independent HUVEC (passages 3-5) and DBMSC (passage 3) preparations.

\section{Culture of HUVEC with different treatments of DBMSCs (conditioned medium, supernatant, and intercellular direct contact) and $\mathrm{H}_{2} \mathrm{O}_{2}$}

HUVEC were cultured alone (Fig. 1a) or with $100 \mu \mathrm{M} \mathrm{H}_{2} \mathrm{O}_{2}$ (Fig. 1b) or with 25\% CMDBMSC and $100 \mu \mathrm{M} \mathrm{H}_{2} \mathrm{O}_{2}$ (Fig. 1c) in a complete endothelial cell growth medium. For the coculture experiments (supernatant and intercellular direct contact), cells (HUVEC and DBMSCs) were separated by transwell chamber membrane culture system [catalogue number 657640, ThinCert ${ }^{\mathrm{TM}}$ Cell Culture Inserts, $0.4 \mu \mathrm{m}$, Greiner Bio-One, Germany]. For soluble factor experiments (SFDBMSC; Fig. 1d), DBMSCs were cultured on the upper compartments while HUVEC

Table 1 Monoclonal antibodies used in this study

\begin{tabular}{|c|c|c|c|c|c|c|c|c|}
\hline Markers & Monoclc & tibodies & & & & & & \\
\hline MSC markers & CD44 & CD90 & CD105 & CD146 & CD166 & $H L A-A B C$ & & \\
\hline Hematopoietic markers & CD14 & CD19 & CD40 & CD45 & CD80 & CD83 & CD86 & HLA-DR \\
\hline Endothelial Cell Marker & CD31 & & & & & & & \\
\hline Adhesion Molecules & ICAM-1 & VCAM-1 & CD44 & & & & & \\
\hline
\end{tabular}




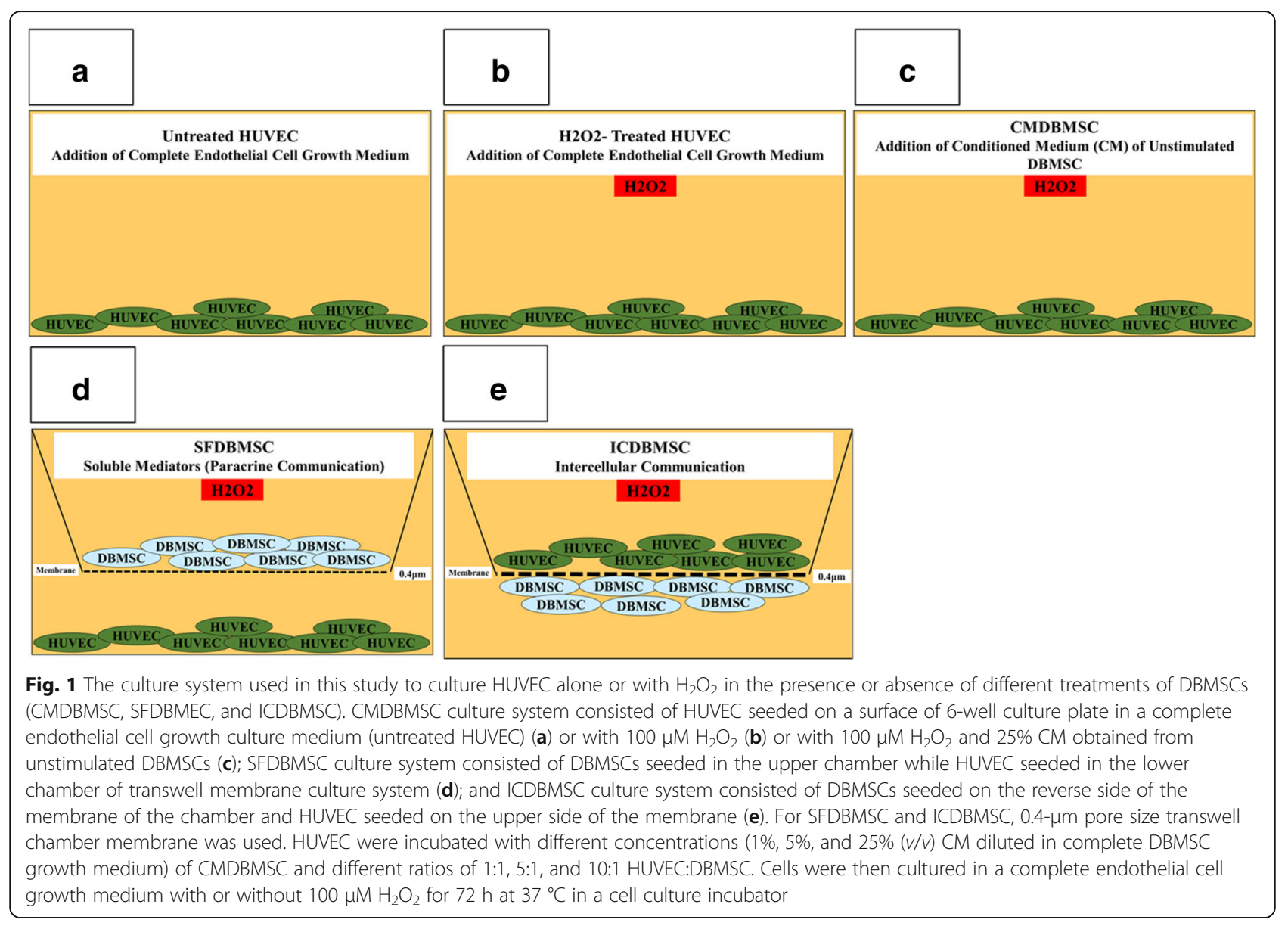

were cultured in the lower compartment. For intercellular direct contact experiments (ICDBMSC; Fig. 1e), DBMSCs were seeded on the reverse side of the membrane of the chamber, and HUVEC were seeded on the upper side of the membrane. In both culture systems, cells were cultured at 5HUVEC:1DBMSC ratio. Cells in the SFDBMSC and ICDBMSC culture systems were then cultured in a complete endothelial cell growth medium in the presence of $100 \mu \mathrm{M} \mathrm{H} \mathrm{H}_{2} \mathrm{O}_{2}$ and incubated as described above. HUVEC were also cultured with CMDBMSC, SFDBMSC, and ICDBMSC without $\mathrm{H}_{2} \mathrm{O}_{2}$. After $48 \mathrm{~h}$ in culture, HUVEC were harvested with TrypLE ${ }^{\mathrm{m}}$ Express detachment solution (Life Technologies) and used in an adhesion, proliferation, and migration experiments as described below. HUVEC viability was determined using Trypan blue. Each experiment was performed and repeated as described above. HUVEC cultured in complete endothelial cell growth medium without DBMSCs were included as a negative control for all HUVEC cultured with different treatments of DBMSCs.

\section{HUVEC adhesion and proliferation using XCELLigence system}

The xCELLigence system (RTCA-DP version; Roche Diagnostics, Mannheim, Germany) was used as we previously described $[12,13]$ to evaluate the adhesion and proliferation of HUVEC. The xCELLigence system is a real-time cell analyzer that constantly monitors and records the changes in electrical impedance, because of cellular events, and these changes are reported as an arbitrary cell index [12, 13]. Briefly, 100- $\mu \mathrm{L}$ complete endothelial cell growth medium was added to well in 16-well culture plates (catalogue number 05469813001, E-Plate 16, Roche Diagnostics), and the background impedance was then achieved as previously described $[12,13]$. Then, $20 \times 10^{4}$ HUVEC (HUVEC were initially co-cultured with DBMSCs and $100 \mu \mathrm{M} \quad \mathrm{H}_{2} \mathrm{O}_{2}$ or cultured alone as described above) were seeded in $100 \mu \mathrm{L}$ of complete endothelial cell growth medium in quadruplicate wells, and equilibrium was achieved by leaving the culture plates for $30 \mathrm{~min}$ at RT before data recording. To record data, culture plates were placed in the xCELLigence system at $37{ }^{\circ} \mathrm{C}$ in a cell culture 
incubator. HUVEC cell index was then automatically monitored for $72 \mathrm{~h}$. For data analysis, the xCELLigence software (version 1.2.1) was used. For cell adhesion, data was measured after $2 \mathrm{~h}$ and the value of cell index was then expressed as mean \pm standard errors of the cell index. For cell proliferation, data was expressed as mean \pm standard errors of the cell index normalized to the cell index recorded after $2 \mathrm{~h}$ (adhesion time point). The rate of cell proliferation was determined by calculating the normalized cell index at 24, 48, and $72 \mathrm{~h}$. Each experiment was performed and repeated as described above.

\section{HUVEC migration using xCELLigence system}

The migration of HUVEC was evaluated using CIM migration plates (catalogue number 05665825001, Roche Diagnostics) in the xCELLigence system as previously described by us $[12,13]$. The CIM plates have 16-migration wells that each consists of two chambers (upper and lower) separated by a membrane (polyethylene terephthalate) with a porous of $8 \mu \mathrm{m}$ in size. The membrane is in contact with microelectrodes. Following the addition of $50-\mu \mathrm{l}$ pre-warmed media to the wells of the upper chamber and 160- $\mu$ l endothelial cell growth medium containing $30 \% \mathrm{FBS}$ to the lower chamber, the plates were then locked in the RTCA DP device at $37{ }^{\circ} \mathrm{C}$ in a cell culture incubator for $1 \mathrm{~h}$ to obtain equilibrium, and a measurement step was then performed as previously described $[12,13]$. The migration experiments were then initiated by seeding $20 \times 10^{3}$ HUVEC [HUVEC were initially co-cultured with DBMSCs and $100 \mu \mathrm{M} \mathrm{H}_{2} \mathrm{O}_{2}$ or cultured with DBMSCs (CMDBMSC, SFDBMSC and ICDBMSC) or cultured alone as described above] in the upper chamber containing $100-\mu \mathrm{L}$ endothelial cell serum free medium and the plates were then incubated for $30 \mathrm{~min}$ at RT to allow the cells to setthe onto the membrane as previously described $[12,13]$. Experiments were performed in quadruplicate, and after equilibration, the impedance value of each well was automatically monitored every $15 \mathrm{~min}$ for $24 \mathrm{~h}$ by the xCELLigence system and then expressed as a cell index value. HUVEC migration observed in the presence and absence of 30\% FBS served as positive and negative controls, respectively. Each experiment was performed and repeated as described above.

\section{HUVEC proliferation in response to monocytes pretreated} with DBMSCs and $\mathrm{H}_{2} \mathrm{O}_{2}$

To evaluate the effects of monocytes pre-treated with DBMSCs on the proliferation of endothelial cells, monocyte proliferation in response to DBMSCs was initially examined by adding DBMSCs to human monocytes (THP-1, catalogue number TIB-202 $2^{\text {tx }}$, ATCC, USA) in 96-well tissue culture plates at different THP-1:DBMSC ratios $(2.5: 1,5: 1,10: 1$, and 20:1 THP-1:DBMSC) in the presence or absence of $100 \mu \mathrm{M} \mathrm{H}_{2} \mathrm{O}_{2}$ (Fig. 2). Cells were then cultured in a complete RPMI-1640 culture medium containing 10\% FBS, $100 \mu \mathrm{g} / \mathrm{mL}$ L-glutamate, and antibiotics. After 24,48 , and $72 \mathrm{~h}$ incubation at $37{ }^{\circ} \mathrm{C}$ in a cell culture incubator, monocyte proliferation was examined using the MTS assay as previously described [12].

Next, endothelial cell proliferation in response to monocytes pre-cultured with DBMSCs and $\mathrm{H}_{2} \mathrm{O}_{2}$ at the indicated ratios (below) in the presence of $100 \mu \mathrm{M} \mathrm{H}_{2} \mathrm{O}_{2}$ was examined (Fig. 2). After 24-h culture with DBMSCs in the presence of $100 \mu \mathrm{M} \mathrm{H}_{2} \mathrm{O}_{2}$, THP-1 [THP-1 alone, THP-1+ $\mathrm{H}_{2} \mathrm{O}_{2}$ (THP-1 pretreated with $\mathrm{H}_{2} \mathrm{O}_{2}$ ), and THP-1/DBMSC $+\mathrm{H}_{2} \mathrm{O}_{2}$ (THP-1 pretreated with DBMSCs and $\mathrm{H}_{2} \mathrm{O}_{2}$ )] were harvested and then added to HUVEC at different THP-1:HUVEC ratios (2.5:1, 5:1, 10:1, and 20:1 THP-1:HUVEC) in the presence of $100 \mu \mathrm{M} \mathrm{H} \mathrm{H}_{2} \mathrm{O}_{2}$. Briefly, THP-1 were added to HUVEC that were initially seeded at a density of $5 \times 10^{3}$ per well in 96-well tissue culture plates. After $24-\mathrm{h}$ culture in a complete HUVEC culture medium at $37^{\circ} \mathrm{C}$ in a cell culture incubator, HUVEC proliferation was examined using the MTS assay as previously described [12]. Before using DBMSCs and THP- 1 in the proliferation assays, cells were treated with $25 \mu \mathrm{g} / \mathrm{ml}$ Mitomycin C to inhibit their proliferation as previously described [12]. Results were presented as means ( \pm standard errors). Each experiment was performed in triplicate and repeated for five times with five independent preparations of DBMSCs and HUVEC. DBMSCs and THP-1 cultured alone were included as negative controls.

\section{Adhesion of monocyte to HUVEC}

DBMSC effect on THP-1 adhesion to HUVECs was examined using our previously published method [12]. Briefly, $\mathrm{H}_{2} \mathrm{O}_{2}$-untreated THP-1 or pretreated with $100 \mu \mathrm{M} \mathrm{H}_{2} \mathrm{O}_{2}$ (TTHP-1) for $24 \mathrm{~h}$ were cocultured with $\mathrm{H}_{2} \mathrm{O}_{2}$-untreated DBMSCs (TTHP-1/UDBMSC) or with $\mathrm{H}_{2} \mathrm{O}_{2}$-treated DBMSCs (TTHP-1/TDBMSC) for $24 \mathrm{~h}$ at 5:1 THP-1:DBMSC ratio in a physical contact experiment by adding THP-1 to DBMSCs that were initially cultured on a plastic surface of 6-well culture plate for $24 \mathrm{~h}$ to allow cells to be fully adhered (Fig. 2). After 24-h incubation in a complete RPMI-1640 culture medium (above), THP-1 were harvested and then labelled with $5 \mu \mathrm{M}$ green fluorescent cell tracker stain (5-chloromethylfluorescin diacetate; CMFDA; Molecular Probes, Life Technologies) for $4 \mathrm{~h}$ as previously described [12]. Following washing THP-1 with fresh RPMI-1640 culture medium, they were added to a monolayer layer of HUVEC at a ratio of 5THP-1:1HUVEC (HUVEC were initially cultured alone or with $100 \mu \mathrm{M} \mathrm{H}_{2} \mathrm{O}_{2}$ for $24 \mathrm{~h}$ ). After incubation for $30 \mathrm{~min}$, non-adherent THP-1 were gently removed by washing with PBS, and the fluorescence intensity of the THP-1 that had adhered to the 


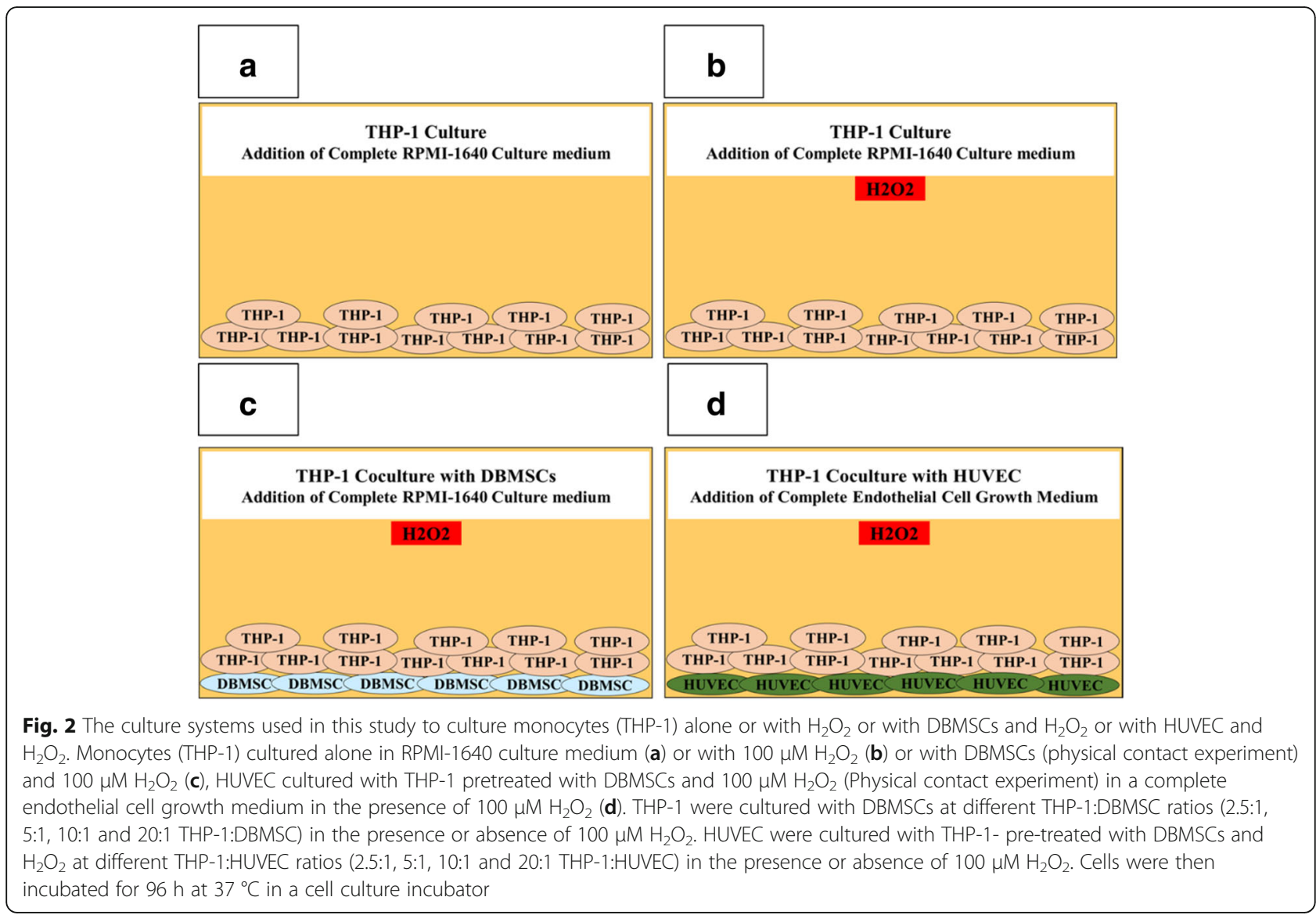

monolayer of HUVEC was then measured at excitation $485 \mathrm{~nm}$ and emission $528 \mathrm{~nm}$ using a fluorescence microplate reader (Glomax Multi Detection System, Promega, Germany). Results were expressed as relative fluorescence intensity (RFI). Different ratios of HUVEC to THP-1 were evaluated. Experiments were performed in triplicate using HUVEC prepared from independent umbilical cord tissue and repeated three times.

\section{Measurement of glutathione reductase activity}

HUVEC (HUVEC were initially co-cultured with DBMSCs and $100 \mu \mathrm{M} \mathrm{H}_{2} \mathrm{O}_{2}$ or cultured alone as described above) were washed twice with cold PBS, and they were then lysed as previously described [12, 13]. Total protein in the supernatant was then determined by Bradford method [12, 13].

The activity of glutathione reductase was measured using OxiSelect ${ }^{\mathrm{ma}}$ Glutathione Reductase Assay Kit (catalogue number STA-812, Cell Biolabs, San Diego, USA) as previously described by us [13]. This assay is based on the reduction of glutathione disulfide (oxidized glutathione) (GSSG) to reduced glutathione (GSH) by glutathione reductase, using NADPH as a donor for $\mathrm{H}$. Subsequently, the chromogen reacts with the thiol group of GSH to produce a colored compound that absorbs at
$405 \mathrm{~nm}$. The glutathione reductase content in HUVEC samples is determined by comparison with the predetermined glutathione reductase standard curve. The assay was performed using 100- $\mu \mathrm{l}$ aliquots of HUVEC supernatant protein immediately after preparation $(30 \mu \mathrm{g}$ protein) added to phosphate buffer containing excess GSSG and NADPH. The level of change was determined at $405 \mathrm{~nm}$ using a standard curve performed. Three experiments were performed in triplicate using HUVEC and DBMSCs as indicated above.

\section{Measurement of thioredoxin reductase activity}

Total protein was extracted from HUVEC (prepared as described above), and thioredoxin reductase (TrxR) activity (catalogue number 10007892, Cayman, Michigan, USA) was then evaluated as per the manufacturer's instructions. This assay is based on the reduction of 5,5'-dithiobis (2-nitrobenzoic) acid (DTNB) with NADPH to 5-thio-2-nitrobenzoic acid, which generates a strong yellow color that can be measured at $412 \mathrm{~nm}$. In the crude biological sample, glutathione reductase and glutathione peroxidase can also be reduced by DTNB. Therefore, TrxR specific inhibitor is used to determine the specific activity of TrxR. Therefore, the total DTNB reduction by the sample is initially estimated and the DTNB reduction 
by the sample in the presence of the TrxR specific inhibitor will then be estimated. The difference between the two results is the DTNB reduction due to TrxR activity. Three experiments were performed in triplicate using HUVEC and DBMSCs as indicated above.

\section{RNA isolation, CDNA synthesis, and real-time polymerase} chain reaction (RT-PCR) analysis

The expression of 84 genes related to endothelial cell biology (catalogue number PAHS-015ZD-24, Qiagen, Hilden, Germany) by HUVEC was determined using QuantiTect Primer Assay (Qiagen, Hilden, Germany) in a real-time polymerase chain reaction (RT-PCR) as previously published [2]. Briefly, total RNA from HUVEC

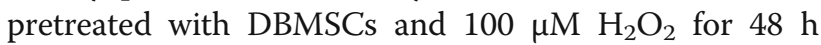
was isolated, and cDNA was then synthesized using FastLane Cell cDNA kit and RT Primer Mix (Qiagen) as previously published [2]. After quantifying mRNA using QuantiTect SYBR Green PCR Kit (Qiagen), the real-time PCR reaction was performed in triplicate on the CFX96 real-time PCR detection system (BIO-RAD) as previously published [2]. To analyze the data, the CFX manager software (Bio-Rad, CA, USA) was used. The results were exported to Microsoft Excel for further analysis. The results were expressed as fold change by calculating the $\Delta \Delta^{-2}$ values. The relative expression of an internal house-keeping gene as a loading control was used as provided in the kit. Experiments were performed in triplicate using HUVEC prepared from independent umbilical cord tissue and repeated three times.

\section{Flow cytometry}

Cells were characterized by flow cytometry as previously described [12]. Briefly, cells $\left(1 \times 10^{5}\right)$ were stained with monoclonal antibodies (Table 1) for $30 \mathrm{~min}$. Cells were then washed twice by adding cold PBS and centrifuged at $150 \times g$ for $5 \mathrm{~min}$ at $8{ }^{\circ} \mathrm{C}$. Unstained and isotype controls were used. Immunoreactivity to cell surface antibody markers or intracellular proteins was assayed by a $\mathrm{BD}$ FACS CANTO II (Becton Dickinson, NJ, USA) flow cytometer.

\section{Statistical analysis}

Data were analyzed using the $t$ test (unpaired $t$ test, two tailed). These analyses were performed using GraphPad Prism 5. Results were considered to be statistically significant if $P<0.05$.

\section{Results}

Isolation and characterization of DBMSCs

MSCs from decidua basalis of human term placenta were previously isolated and characterized by us [2]. DBMSCs at passage 3 were positive (>95\%) for MSC markers and negative for hematopoietic markers and were able to differentiate into adipocytes, chondrocytes, and osteocytes as previously report [2]. Subsequently, DBMSCs at passage 3 were used in all experiments.

DBMSCs and $\mathrm{H}_{2} \mathrm{O}_{2}$ modulated the proliferation of HUVEC To evaluate the effects of DBMSCs on endothelial cell functions, the proliferation of HUVEC cultured with DBMSCs in the presence or absence of $100 \mu \mathrm{M} \mathrm{H} \mathrm{H}_{2} \mathrm{O}_{2}$ was examined using the MTS assay. The viability HUVEC exposed to $100 \mu \mathrm{M} \mathrm{H}_{2} \mathrm{O}_{2}$ was more than $90 \%$ at all culture time points $(24,48$, and $72 \mathrm{~h}$ ). This was consistent with our previous report [13]. The exposure of HUVEC to concentrations higher than $100 \mu \mathrm{M} \mathrm{H}_{2} \mathrm{O}_{2}$ reduced their viability to less than $50 \%$, as we previously reported [13]. Consequently, $100 \mu \mathrm{M} \mathrm{H}_{2} \mathrm{O}_{2}$ was used in this study.

The effects of $\mathrm{H}_{2} \mathrm{O}_{2}$ on HUVEC proliferation maintained throughout the culture times (24, 48, and $72 \mathrm{~h}$ ), but the addition of DBMSCs (CMDBMSC and DBMSCs) significantly $(P<0.05)$ induced the effect of $\mathrm{H}_{2} \mathrm{O}_{2}$ on HUVEC proliferation after $48 \mathrm{~h}$ in culture at all examined concentrations of CMDBMSC and ratios of DBMSCs, respectively, as compared to untreated HUVEC or $\mathrm{H}_{2} \mathrm{O}_{2}$-treated HUVEC, $P<0.05$ (Fig. 3a, b), and had no significant changes on the effect of $\mathrm{H}_{2} \mathrm{O}_{2}$ on HUVEC proliferation after 24 and $72 \mathrm{~h}$ in culture, $P>0.05$. Consequently, the culture time used in this study was $48 \mathrm{~h}$. HUVEC proliferation was also significantly increased in response to at all examined concentrations of CMDBMSC, $P<0.05$ (Fig. 3a), and only at a high ratio of DBMSCs to HUVEC (1:1), $P<0.05$ (Fig. 3b) as compared to untreated HUVEC. As compared to HUVEC cultured with CMDBMSC, HUVEC proliferation did not significantly change in response to $\mathrm{H}_{2} \mathrm{O}_{2}$ and CMDBMSCs, $P>0.05$ (Fig. 3a). As compared to HUVEC cultured with low ratios of DBMSCs to HUVEC (1:5 and 1:10), HUVEC proliferation significantly increased in response to $\mathrm{H}_{2} \mathrm{O}_{2}$ and DBMSCs, $P<0.05$ (Fig. 3b).

\section{The effects of DBMSCs and $\mathrm{H}_{2} \mathrm{O}_{2}$ on HUVEC proliferation are reversible}

To evaluate the reversibility of DBMSC effects on the proliferation of $\mathrm{H}_{2} \mathrm{O}_{2}$-treated HUVEC, HUVEC were initially cultured with different treatments of DBMSCs in the presence of $100 \mu \mathrm{M} \mathrm{H}_{2} \mathrm{O}_{2}$ for $48 \mathrm{~h}$ and their proliferation was then determined using the xCELLigence system. After 24, 48, and $72 \mathrm{~h}$, the proliferation of HUVEC pretreated with $\mathrm{H}_{2} \mathrm{O}_{2}$ (HUVEC $+\mathrm{H}_{2} \mathrm{O}_{2}$ ) and HUVEC pretreated with $\mathrm{H}_{2} \mathrm{O}_{2}$ and with different treatments of DBMSCs (CMDBMSC $+\mathrm{H}_{2} \mathrm{O}_{2}$, SFDBMSC + $\mathrm{H}_{2} \mathrm{O}_{2}$, and ICDBMSC $+\mathrm{H}_{2} \mathrm{O}_{2}$ ) significantly reduced as compared to untreated HUVEC, $P<0.05$ (Fig. 4a-c). Similarly, after 24,48 , and $72 \mathrm{~h}$, the proliferation of 


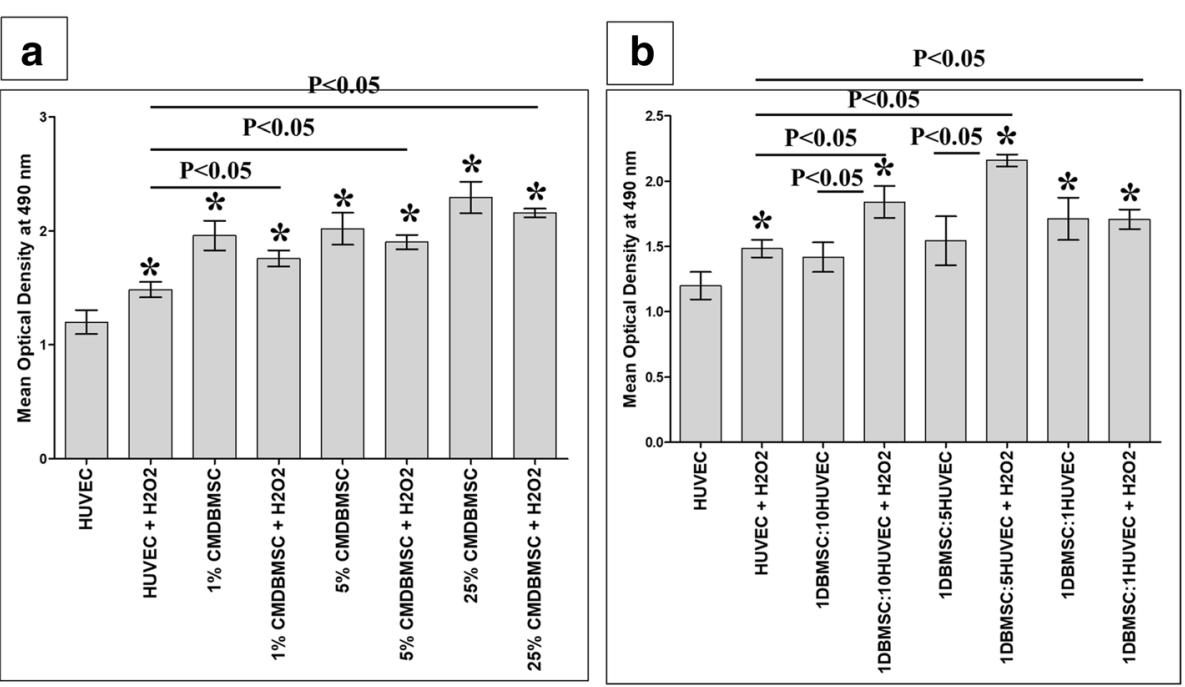

Fig. 3 Proliferation of HUVEC measured by MTS. As compared to untreated HUVEC, the proliferation of HUVEC significantly increased in response to $\mathrm{H}_{2} \mathrm{O}_{2}$ alone or with different concentrations (1\%, 5\%, and 25\%) of CMDBMSC in the presence of $100 \mu \mathrm{M} \mathrm{H}_{2} \mathrm{O}_{2}$ (a) and with different ratios of DBMSC to HUVEC $\left(1: 1,1: 5\right.$, and 1:10) in the presence of $100 \mu \mathrm{M} \mathrm{H}_{2} \mathrm{O}_{2}$ (b). As compared to HUVEC treated with $\mathrm{H}_{2} \mathrm{O}_{2}\left(\mathrm{HUVEC}+\mathrm{H}_{2} \mathrm{O}_{2}\right)$, the proliferation of HUVEC significantly increased in response to different concentrations (1\%, 5\% and 25\%) of CMDBMSC in presence of $100 \mu \mathrm{M} \mathrm{H}_{2} \mathrm{O}_{2}$ (a) and with different ratios of DBMSC to HUVEC (1:1, 1:5, and 1:10) in presence of $100 \mu \mathrm{M} \mathrm{H}_{2} \mathrm{O}_{2}$ (b). As compared to untreated HUVEC, HUVEC proliferation significantly increased in response to different concentrations (1\%,5\%, and $25 \%)$ of CMDBMSC (a), and at a high ratio of DBMSC to HUVEC (1:1) (b). As compared to HUVEC cultured with CMDBMSC, HUVEC proliferation did not significantly change in response to $\mathrm{H}_{2} \mathrm{O}_{2}$ and CMDBMSCs, $P>0.05$ (a). As compared to HUVEC cultured with low ratios of DBMSCs to HUVEC (1:5 and 1:10), HUVEC proliferation significantly increased in response to $\mathrm{H}_{2} \mathrm{O}_{2}$ and DBMSCs (b). ${ }^{*} P<0.05$. Bars represent standard errors. Each experiment was performed in triplicate and repeated for five times with five independent preparations of DBMSCs and HUVEC

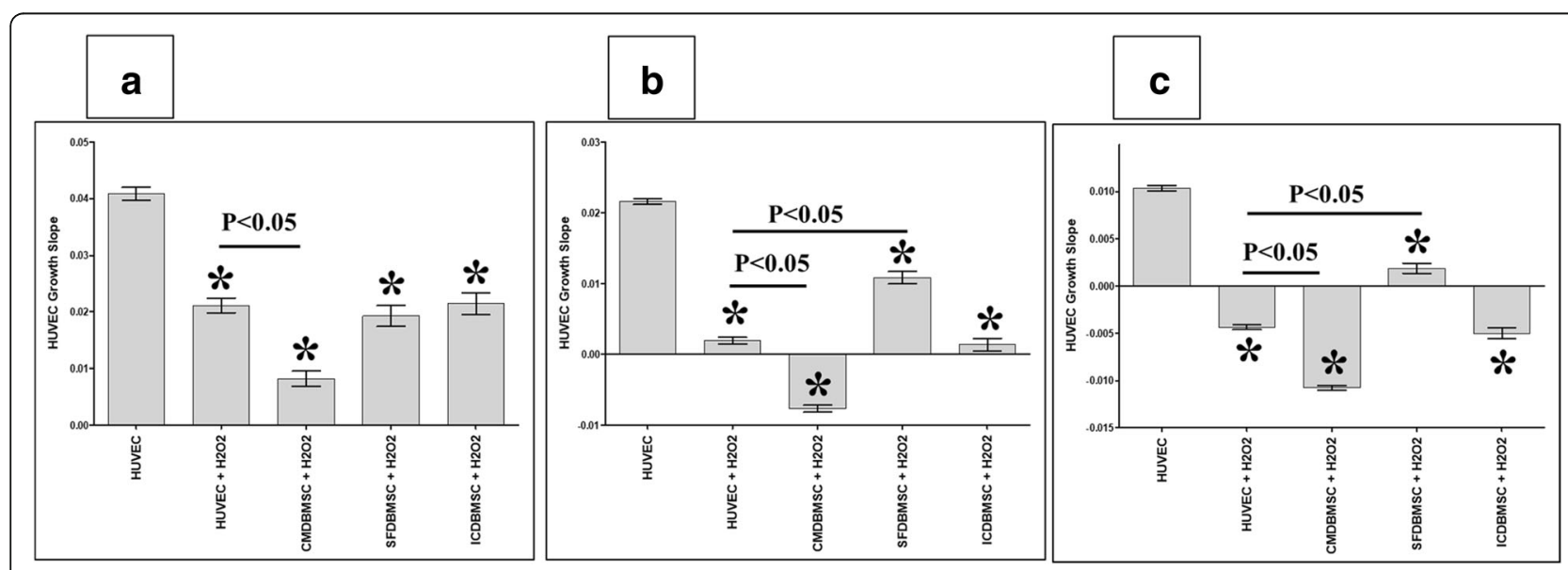

Fig. 4 The proliferation of HUVEC after removing the effects of DBMSCs and $\mathrm{H}_{2} \mathrm{O}_{2}$. HUVEC were initially cultured with DBMSCs and $100 \mu M M \mathrm{H}_{2} \mathrm{O}_{2}$ for $48 \mathrm{~h}$ and then used in a proliferation assay using the xCELLigence real-time cell analyzer. After $24(\mathbf{a}), 48(\mathbf{b})$, and 72 (c) hours, the proliferation of HUVEC pretreated with $\mathrm{H}_{2} \mathrm{O}_{2}\left(\mathrm{HUVEC}+\mathrm{H}_{2} \mathrm{O}_{2}\right.$ ) or with $\mathrm{H}_{2} \mathrm{O}_{2}$ and CMDBMSC (CMDBMSC $+\mathrm{H}_{2} \mathrm{O}_{2}$ ) or with $\mathrm{H}_{2} \mathrm{O}_{2}$ and SFDBMSC (SFDBMSC + $\mathrm{H}_{2} \mathrm{O}_{2}$ ) or with $\mathrm{H}_{2} \mathrm{O}_{2}$ and ICDBMSC (ICDBMSC $+\mathrm{H}_{2} \mathrm{O}_{2}$ ) significantly reduced as compared to untreated HUVEC. After 24, 48, and $72 \mathrm{~h}$, the proliferation of HUVEC pretreated with $\mathrm{H}_{2} \mathrm{O}_{2}$ and CMDBMSC (CMDBMSC $+\mathrm{H}_{2} \mathrm{O}_{2}$ ) significantly reduced as compared to HUVEC pretreated with $\mathrm{H}_{2} \mathrm{O}_{2}\left(\mathrm{HUVEC}+\mathrm{H}_{2} \mathrm{O}_{2}\right)(\mathbf{a}-\mathbf{c})$. The proliferation of HUVEC pretreated with $\mathrm{H}_{2} \mathrm{O}_{2}$ and SFDBMSC (SFDBMSC $+\mathrm{H}_{2} \mathrm{O}_{2}$ ) significantly increased after 48 and $72 \mathrm{~h}$ as compared to $\mathrm{H}_{2} \mathrm{O}_{2}$-treated HUVEC (HUVEC $\left.+\mathrm{H}_{2} \mathrm{O}_{2}\right)(\mathbf{b}, \mathbf{c})$, but did not change significantly after $24 \mathrm{~h}(P>0.05)(\mathbf{a})$. The proliferation of HUVEC pretreated with $\mathrm{H}_{2} \mathrm{O}_{2}$ and ICDBMSC (ICDBMSC $+\mathrm{H}_{2} \mathrm{O}_{2}$ ) was not significantly changed $(P>0.05)$ as compared to $\mathrm{H}_{2} \mathrm{O}_{2}$-treated $\mathrm{HUVEC}$ $\left(\mathrm{HUVEC}+\mathrm{H}_{2} \mathrm{O}_{2}\right)(\mathbf{a}-\mathbf{c})$. Each experiment was performed in triplicate and repeated with five independent HUVEC (passages 3-5) and DBMSC (passage 3 ) preparations. ${ }^{*} P<0.05$. Bars represent standard errors 
HUVEC pretreated with $\mathrm{H}_{2} \mathrm{O}_{2}$ and CMDBMSC (CMDBMSC $+\mathrm{H}_{2} \mathrm{O}_{2}$ ) significantly reduced as compared to HUVEC pretreated with $\mathrm{H}_{2} \mathrm{O}_{2}, P<0.05$ (Fig. 4a-c). In contrast, after 48 and $72 \mathrm{~h}$, and as compared to HUVEC pretreated with $\mathrm{H}_{2} \mathrm{O}_{2}$, the proliferation of HUVEC pretreated with $\mathrm{H}_{2} \mathrm{O}_{2}$ and SFDBMSC (SFDBMSC $+\mathrm{H}_{2} \mathrm{O}_{2}$ ) significantly increased $(P<0.05)$, but did not change significantly after $24 \mathrm{~h}, P>0.05$ (Fig. $4 \mathrm{a}-\mathrm{c}$ ). In addition, the culture with ICDBMSC (ICDBMSC $+\mathrm{H}_{2} \mathrm{O}_{2}$ ) did not significantly affect the proliferation of HUVEC pretreated with $\mathrm{H}_{2} \mathrm{O}_{2}$ as compared to HUVEC pretreated with $\mathrm{H}_{2} \mathrm{O}_{2}$ at all examined time points in culture, $P>0.05$ (Fig. $4 \mathrm{a}-\mathrm{C}$ ).

\section{DBMSCs and $\mathrm{H}_{2} \mathrm{O}_{2}$ modulated HUVEC adhesion}

To study the effects of DBMSCs on the adhesion of $\mathrm{H}_{2} \mathrm{O}_{2}$-treated HUVEC, HUVEC were initially cultured with different treatments of DBMSCs in the presence of $100 \mu \mathrm{M} \mathrm{H}_{2} \mathrm{O}_{2}$ for $48 \mathrm{~h}$ and their adhesion was then determined using the $\mathrm{xCELLigence} \mathrm{system.} \mathrm{After} 2 \mathrm{~h}$, the adhesion of HUVEC pretreated with $\mathrm{H}_{2} \mathrm{O}_{2}$ (HUVEC + $\mathrm{H}_{2} \mathrm{O}_{2}$ ) and HUVEC pretreated with $\mathrm{H}_{2} \mathrm{O}_{2}$ and different treatments of DBMSCs (CMDBMSC $+\mathrm{H}_{2} \mathrm{O}_{2}$ and SFDBMSC $+\mathrm{H}_{2} \mathrm{O}_{2}$ ) significantly increased as compared to untreated HUVEC, $P<0.05$ (Fig. 5). In contrast, culturing with ICDBMSC (ICDBMSC $+\mathrm{H}_{2} \mathrm{O}_{2}$ ) decreased the adhesion of $\mathrm{H}_{2} \mathrm{O}_{2}$-treated HUVEC, but not significantly as compared to untreated HUVEC, $P>0.05$ (Fig. 5). As compared to $\mathrm{H}_{2} \mathrm{O}_{2}$-treated HUVEC, the adhesion of $\mathrm{H}_{2} \mathrm{O}_{2}$-treated HUVEC cultured with SFDBMSC and ICDBMSC (SFDBMSC+ $\mathrm{H}_{2} \mathrm{O}_{2}$ and ICDBMSC $+\mathrm{H}_{2} \mathrm{O}_{2}$ ) significantly increased and reduced, respectively $(P<0.05)$ (Fig. 5$)$. In contrast, culturing with CMDBMSC (CMDBMSC $+\mathrm{H}_{2} \mathrm{O}_{2}$ ) had no significant changes on the adhesion of $\mathrm{H}_{2} \mathrm{O}_{2}$-treated HUVEC as compared to $\mathrm{H}_{2} \mathrm{O}_{2}$-treated HUVEC cultured alone, $P>0.05$ (Fig. 5).

\section{DBMSCs and $\mathrm{H}_{2} \mathrm{O}_{2}$ modulated HUVEC migration}

To further study the effect of DBMSCs and $\mathrm{H}_{2} \mathrm{O}_{2}$ on the migration of endothelial cells, HUVEC were initially cultured with different treatment of DBMSCs in the presence of $100 \mu \mathrm{M} \mathrm{H}_{2} \mathrm{O}_{2}$ (CMDBMSC $+\mathrm{H}_{2} \mathrm{O}_{2}$, SFDBMSC $+\mathrm{H}_{2} \mathrm{O}_{2}$, and ICDBMSC $+\mathrm{H}_{2} \mathrm{O}_{2}$ ) or in the absence of $\mathrm{H}_{2} \mathrm{O}_{2}$ (CMDBMSC, SFDBMSC, and ICDBMSC) for $48 \mathrm{~h}$ and then re-cultured in a 16-well migration culture plate and monitored using the xCELLigence system. After $24 \mathrm{~h}$, the migration of $\mathrm{H}_{2} \mathrm{O}_{2}$-treated HUVEC (HUVEC + $\mathrm{H}_{2} \mathrm{O}_{2}$ ) cultured alone or with CMDBMSC (ICDBMSC + $\mathrm{H}_{2} \mathrm{O}_{2}$ ) significantly reduced as compared to untreated HUVEC, $P<0.05$ (Fig. 6). In contrast, the migration of $\mathrm{H}_{2} \mathrm{O}_{2}$-treated HUVEC cultured with SFDBMSC and ICDBMSC (SFDBMSC $+\mathrm{H}_{2} \mathrm{O}_{2}$ and ICDBMSC $+\mathrm{H}_{2} \mathrm{O}_{2}$ ) did not change significantly as compared to untreated

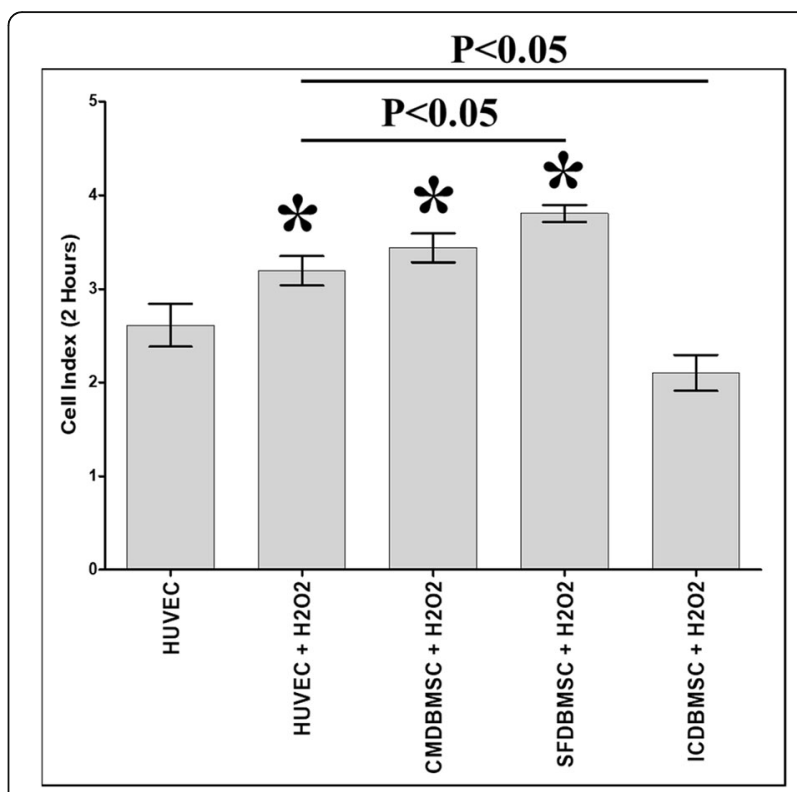

Fig. 5 The adhesion of HUVEC after removing the effects of DBMSCs and $\mathrm{H}_{2} \mathrm{O}_{2}$. HUVEC were initially cultured with DBMSC with $100 \mu \mathrm{M}$ $\mathrm{H}_{2} \mathrm{O}_{2}$ for $48 \mathrm{~h}$ and then used in an adhesion assay using the xCELLigence real-time cell analyzer. After $2 \mathrm{~h}$, the adhesion of HUVEC pretreated with $\mathrm{H}_{2} \mathrm{O}_{2}$ alone $\left(\mathrm{HUVEC}+\mathrm{H}_{2} \mathrm{O}_{2}\right)$ or with $\mathrm{H}_{2} \mathrm{O}_{2}$ and CMDBMSC (CMDBMSC $+\mathrm{H}_{2} \mathrm{O}_{2}$ ) or with $\mathrm{H}_{2} \mathrm{O}_{2}$ and SFDBMSC ( $\mathrm{SFDBMSC}+\mathrm{H}_{2} \mathrm{O}_{2}$ ) significantly increased as compared to untreated HUVEC while the adhesion of HUVEC pretreated with $\mathrm{H}_{2} \mathrm{O}_{2}$ and ICDBMSC (ICDBMSC $\left.+\mathrm{H}_{2} \mathrm{O}_{2}\right)$ reduced, but not significantly $(P>0.05)$. After $2 \mathrm{~h}$ and as compared with HUVEC pretreated with $\mathrm{H}_{2} \mathrm{O}_{2}$ ( $\mathrm{HUVEC}+\mathrm{H}_{2} \mathrm{O}_{2}$ ), the adhesion of HUVEC pretreated with $\mathrm{H}_{2} \mathrm{O}_{2}$ and SFDBMSC (SFDBMSC $+\mathrm{H}_{2} \mathrm{O}_{2}$ ) or ICDBMSC (ICDBMSC $+\mathrm{H}_{2} \mathrm{O}_{2}$ ) significantly increased and decreased, respectively. Each experiment was performed in triplicate and repeated with five independent HUVEC (passages 3-5) and DBMSC (passage 3) preparations. ${ }^{*} P<$ 0.05 . Bars represent standard errors

HUVEC $(P>0.05)$, but significantly increased as compared to $\mathrm{H}_{2} \mathrm{O}_{2}$-treated HUVEC, $P<0.05$ (Fig. 6). The incubation with CMDBMSC (CMDBMSC+ $\mathrm{H}_{2} \mathrm{O}_{2}$ ) reduced the migration of $\mathrm{H}_{2} \mathrm{O}_{2}$-treated $\mathrm{HUVEC}$, but not significantly $(P>0.05)$ as compared to $\mathrm{H}_{2} \mathrm{O}_{2}$-treated HUVEC (Fig. 6). After $24 \mathrm{~h}$, the migration of HUVEC treated with CMDBMSC or SFDBMSC did not significantly change as compared to untreated HUVEC, $P>$ 0.05 (Fig. 6). In contrast, the migration of HUVEC treated with ICDBMSC significantly increased as compared to untreated HUVEC, $P<0.05$ (Fig. 6). As compared to HUVEC treated with CMDBMSC, SFDBMSC, or ICDBMSC, the migration of HUVEC treated with $\mathrm{H}_{2} \mathrm{O}_{2}$ in the presence of CMDBMSC or SFDBMSC or ICDBMSC did not significantly change, $P>0.05$ (Fig. 6).

\section{DBMSCs reduced the stimulatory effect of monocytes and $\mathrm{H}_{2} \mathrm{O}_{2}$ on HUVEC proliferation}

To study the effect of DBMSCs on the interaction between monocytes and $\mathrm{H}_{2} \mathrm{O}_{2}$ (THP-1 $+\mathrm{H}_{2} \mathrm{O}_{2}$ ) on the 


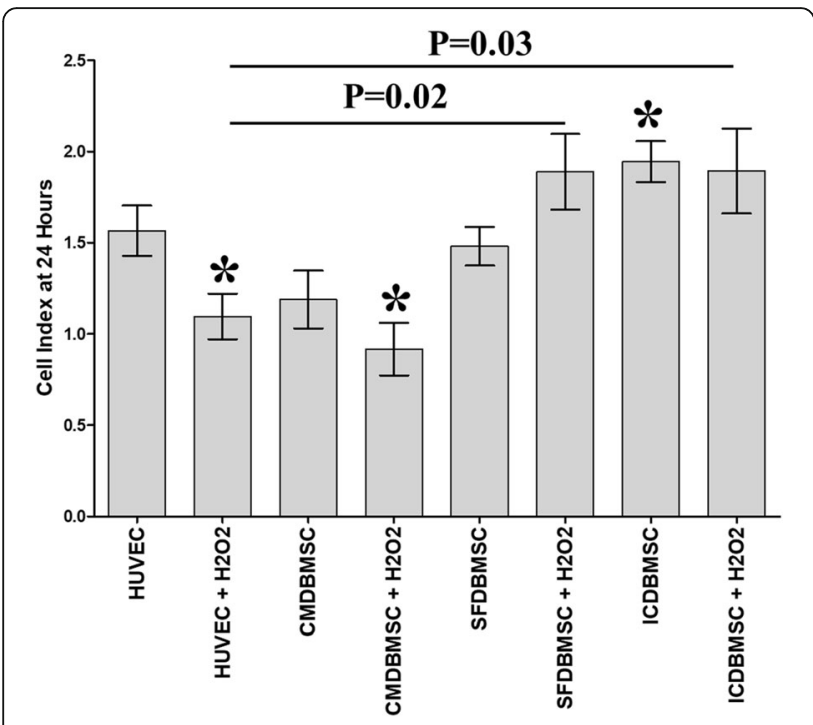

Fig. 6 The migration of HUVEC after removing the effects of DBMSCs and $\mathrm{H}_{2} \mathrm{O}_{2}$. HUVEC were initially cultured with DBMSC with $100 \mu \mathrm{M} \mathrm{H}_{2} \mathrm{O}_{2}$ for $48 \mathrm{~h}$ and then used in a migration assay using the xCELLigence real-time cell analyzer. After $24 \mathrm{~h}$, the migration of HUVEC pretreated with $\mathrm{H}_{2} \mathrm{O}_{2}$ alone $\left(\mathrm{HUVEC}+\mathrm{H}_{2} \mathrm{O}_{2}\right.$ ) or with $\mathrm{H}_{2} \mathrm{O}_{2}$ and CMDBMSC (CMDBMSC $+\mathrm{H}_{2} \mathrm{O}_{2}$ ) significantly reduced as compared to untreated HUVEC while the migration of HUVEC pretreated with $\mathrm{H}_{2} \mathrm{O}_{2}$ and with SFDBMSC (SFDBMSC $+\mathrm{H}_{2} \mathrm{O}_{2}$ ) or $\mathrm{H}_{2} \mathrm{O}_{2}$ and ICDBMSC (ICDBMSC $+\mathrm{H}_{2} \mathrm{O}_{2}$ ) increased, but not significantly $(P>0.05)$. After $24 \mathrm{~h}$, the migration of HUVEC pretreated with $\mathrm{H}_{2} \mathrm{O}_{2}$ and with SFDBMSC (SFDBMSC $+\mathrm{H}_{2} \mathrm{O}_{2}$ ) or with ICDBMSC (ICDBMSC $+\mathrm{H}_{2} \mathrm{O}_{2}$ ) significantly increased as compared to HUVEC pretreated with $\mathrm{H}_{2} \mathrm{O}_{2}$ (HUVEC $+\mathrm{H}_{2} \mathrm{O}_{2}$ ). After $24 \mathrm{~h}$ and as compared to untreated HUVEC, the migration of HUVEC treated with CMDBMSC or SFDBMSC did not significantly change, $P>0.05$. In contrast, the migration of HUVEC treated with ICDBMSC significantly increased as compared to untreated HUVEC after $24 \mathrm{~h}$. After $24 \mathrm{~h}$ and as compared to HUVEC treated with CMDBMSC, SFDBMSC, or ICDBMSC, the migration of HUVEC treated with $\mathrm{H}_{2} \mathrm{O}_{2}$ in the presence of CMDBMSC or SFDBMSC or ICDBMSC did not significantly change, $P>0.05$. Each experiment was performed in triplicate and repeated with five independent HUVEC (passages 3-5) and DBMSC (passage 3) preparations. ${ }^{*} P<0.05$. Bars represent standard errors

proliferation of HUVEC, the effect of DBMSCs on the proliferation of monocytes in the presence of $\mathrm{H}_{2} \mathrm{O}_{2}$ (THP-1:DBMSC $+\mathrm{H}_{2} \mathrm{O}_{2}$ ) was first examined using the MTS assay. Then, the proliferation of HUVEC in response to monocytes pre-cultured with DBMSCs and $\mathrm{H}_{2} \mathrm{O}_{2}$ (HUVEC:THP-1/DBMSC $+\mathrm{H}_{2} \mathrm{O}_{2}$ ) was also evaluated. After 24-h culture with DBMSCs, the proliferation of monocytes cultured with $\mathrm{H}_{2} \mathrm{O}_{2}$ and DBMSCs (THP-1:DBMSC $+\mathrm{H}_{2} \mathrm{O}_{2}$ ) at all examined ratios of monocytes and DBMSCs significantly increased, $P<0.05$ (Fig. 7a) as compared to monocytes cultured alone or with $\mathrm{H}_{2} \mathrm{O}_{2}$ (THP-1 $+\mathrm{H}_{2} \mathrm{O}_{2}$ ). This stimulatory effect of DBMSCs on the proliferation of monocytes is reversible and time dependent (data not shown). The effect of DBMSCs on the proliferation of monocytes (THP-1) alone was also evaluated. After 24-h culture with DBMSCs, THP-1 proliferation at all examined ratios of monocytes and DBMSCs significantly increased, $P<0.05$ (Fig. 7a) as compared to monocytes cultured alone. Following the addition of $\mathrm{H}_{2} \mathrm{O}_{2}$ to monocyte cultured with DBMSCs, monocyte proliferation did not significantly change as compared to monocytes cultured with $\mathrm{H}_{2} \mathrm{O}_{2}$ alone, $P>0.05$ (Fig. 7a).

After $24 \mathrm{~h}$, the proliferation of HUVEC cultured in $\mathrm{H}_{2} \mathrm{O}_{2}$ significantly increased after the addition of a high ratio of monocytes pretreated with $\mathrm{H}_{2} \mathrm{O}_{2}$ (THP-1 + $\mathrm{H}_{2} \mathrm{O}_{2}$ ) to HUVEC (1HUVEC:10THP- $1+\mathrm{H}_{2} \mathrm{O}_{2}$ ), and this stimulatory effect of monocytes pretreated with $\mathrm{H}_{2} \mathrm{O}_{2}$ on HUVEC proliferation was significantly reduced $(P<0.05)$ by monocytes pretreated with DBMSCs and $\mathrm{H}_{2} \mathrm{O}_{2}$ (THP-1/DBMSC $+\mathrm{H}_{2} \mathrm{O}_{2}$ ), $P<0.05$ (Fig. 7b). This stimulatory effect of monocytes pretreated with $\mathrm{H}_{2} \mathrm{O}_{2}$ (THP-1 $+\mathrm{H}_{2} \mathrm{O}_{2}$ ) on the proliferation of HUVEC cultured in $\mathrm{H}_{2} \mathrm{O}_{2}$ and the inhibitory effect of DBMSCs on monocytes pretreated with $\mathrm{H}_{2} \mathrm{O}_{2}$ (THP-1/DBMSC $+\mathrm{H}_{2} \mathrm{O}_{2}$ ) inducing the proliferation of HUVEC cultured in $\mathrm{H}_{2} \mathrm{O}_{2}$ are reversible and time dependent (data not shown). The effects of DBMSCs on the proliferative responses of HUVEC cultured with or without $\mathrm{H}_{2} \mathrm{O}_{2}$ and monocytes pretreated with or without $\mathrm{H}_{2} \mathrm{O}_{2}$ were not significantly changed, $P>0.05$ (data not shown).

\section{DBMSCs reduced the adhesion of $\mathrm{H}_{2} \mathrm{O}_{2}$-treated monocytes to HUVEC}

To evaluate the effect of DBMSCs on the adhesion of monocytes to endothelial cells, monocytes pretreated with $\mathrm{H}_{2} \mathrm{O}_{2}$ (TTHP-1) were cultured with $\mathrm{H}_{2} \mathrm{O}_{2}$-untreated DBMSCs (UDBMSC) or DBMSC pretreated with $\mathrm{H}_{2} \mathrm{O}_{2}$ (TDBMSC) for $24 \mathrm{~h}$, and THP-1 were then harvested and labelled with the green fluorescent dye CMFDA and added to endothelial cells (HUVEC were initially cultured alone or with $100 \mu \mathrm{M} \mathrm{H}_{2} \mathrm{O}_{2}$ for $24 \mathrm{~h}$ ) in an adhesion assay. Results showed that the adhesion of monocytes pretreated with $\mathrm{H}_{2} \mathrm{O}_{2}$ to endothelial cells (HUVEC were initially cultured alone or with $\mathrm{H}_{2} \mathrm{O}_{2}$ ) was significantly reduced after culturing with UDBMSC or TDBMSC, $P<0.05$ (Fig. 8a, b). There was no difference in the adhesion of $\mathrm{H}_{2} \mathrm{O}_{2}$-untreated monocytes and $\mathrm{H}_{2} \mathrm{O}_{2}$-treated monocytes to endothelial cells by DBMSCs (data not shown).

Next, we studied that the inhibitory effects of DBMSCs on the adhesion of monocytes pretreated with $\mathrm{H}_{2} \mathrm{O}_{2}$ to endothelial cells were mediated by modulating the expression of adhesion molecules by monocytes pretreated with $\mathrm{H}_{2} \mathrm{O}_{2}$. A range of adhesion molecules were studied by flow cytometry and expression recorded as median fluorescence intensity or as a percentage of cells. After $24 \mathrm{~h}$, the expression of ICAM-1 in monocytes pretreated with $\mathrm{H}_{2} \mathrm{O}_{2}$ (TTHP-1) was significantly increased 


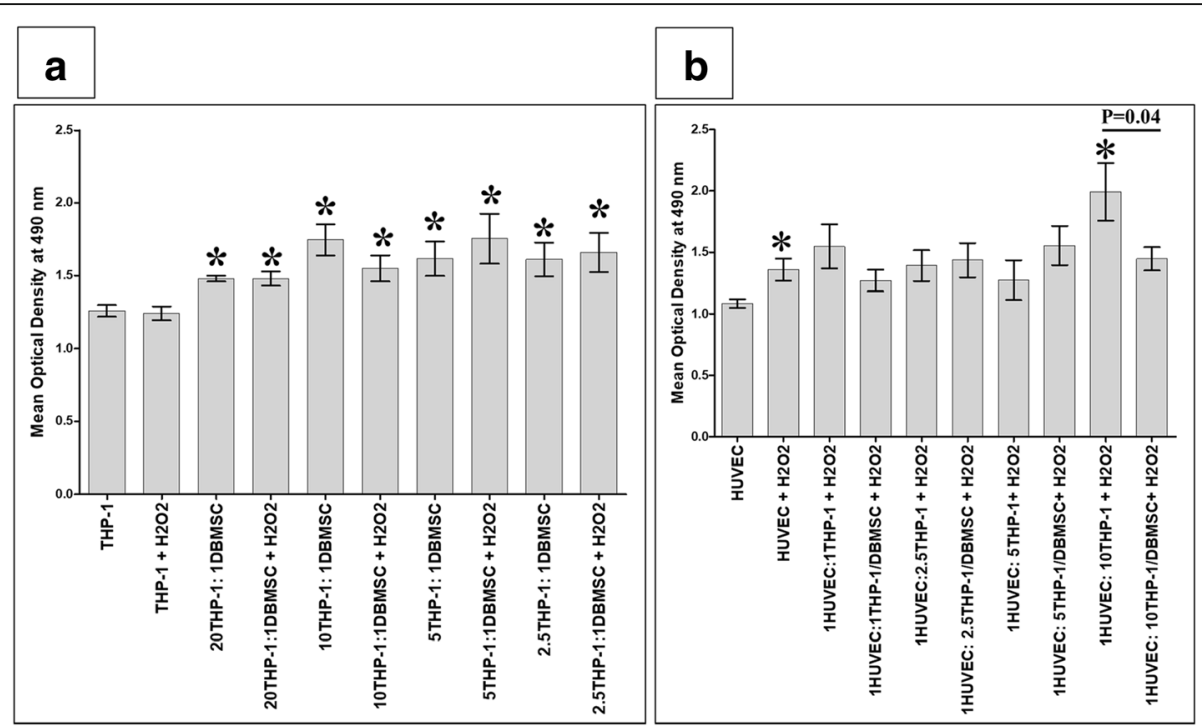

Fig. 7 The proliferation of monocytes (THP-1) and HUVEC evaluated by the MTS assay. After $24 \mathrm{~h}$ and as compared to untreated THP-1, the proliferation of THP-1 in the presence of $\mathrm{H}_{2} \mathrm{O}_{2}$ and DBMSCs (THP-1/DBMSC $+\mathrm{H}_{2} \mathrm{O}_{2}$ ) significantly increased at different THP-1 and DBMSC ratios (20:1, 10:1, 5:1, and 2.5:1) (a). After $24 \mathrm{~h}$ and as compared with untreated HUVEC, the proliferation of $\mathrm{H}_{2} \mathrm{O}_{2}$-treated HUVEC (HUVEC $\left.+\mathrm{H}_{2} \mathrm{O}_{2}\right)$ and $\mathrm{H}_{2} \mathrm{O}_{2}$-treated HUVEC in the presence of THP-1 pretreated with $\mathrm{H}_{2} \mathrm{O}_{2}\left(\right.$ THP-1 $+\mathrm{H}_{2} \mathrm{O}_{2}$ ) at 1:10 HUVEC:THP-1 ratio significantly increased (b). The proliferation of $\mathrm{H}_{2} \mathrm{O}_{2}$-treated HUVEC in the presence of THP-1 pretreated with $\mathrm{H}_{2} \mathrm{O}_{2}$ and DBMSCS (THP-1/DBMSC $+\mathrm{H}_{2} \mathrm{O}_{2}$ ) significantly reduced as compared with $\mathrm{H}_{2} \mathrm{O}_{2}$-treated HUVEC cultured with THP-1 pretreated with $\mathrm{H}_{2} \mathrm{O}_{2}$ (b). After $24 \mathrm{~h}$ culture with DBMSCs and as compared to monocytes cultured alone, the proliferation of THP-1 significantly increased at all examined ratios of monocytes and DBMSCs (a). As compared to monocytes cultured with $\mathrm{H}_{2} \mathrm{O}_{2}$ alone, the proliferation of monocyte cultured with DBMSCs did not significantly change, $P>0.05$ (a). Each experiment was performed in triplicate and repeated for five times with five independent preparations of DBMSCs and HUVEC. ${ }^{*} P<0.05$. Bars represent standard errors

a

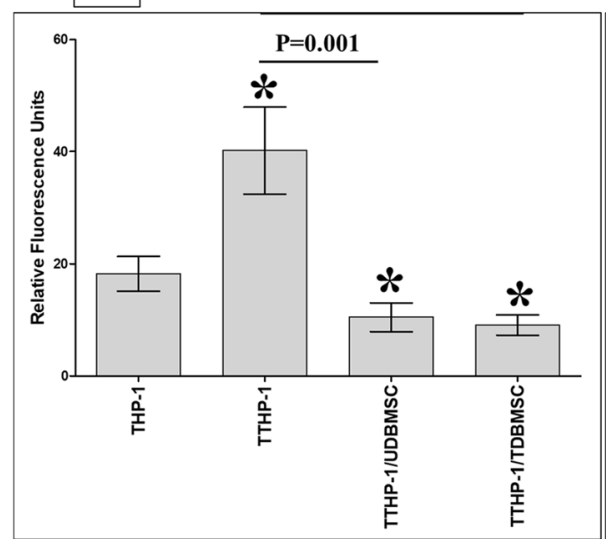

b

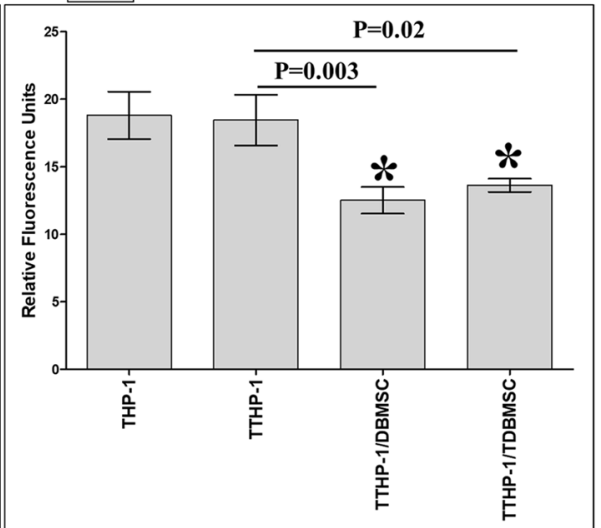

Fig. 8 The adhesion of monocytes (THP-1) to HUVEC was evaluated by measuring THP-1 fluorescence intensity using a fluorescence microplate reader. THP-1 were initially cultured alone (THP-1) or with $100 \mu \mathrm{M} \mathrm{H}_{2} \mathrm{O}_{2}$ (TTHP-1) for $24 \mathrm{~h}$ and then cultured with DBMSCs (5:1 THP-1:DBMSC ratio) that were initially cultured alone (UDBMSC) or with $100 \mu \mathrm{M} \mathrm{H}_{2} \mathrm{O}_{2}$ (TDBMSC) for $24 \mathrm{~h}$. After $24 \mathrm{~h}$ culture, THP-1 were labelled with $5 \mu \mathrm{M}$ green fluorescent cell tracker stain CMFDA and added to HUVEC monolayer (HUVEC were initially cultured with or without $100 \mu \mathrm{M} \mathrm{H}_{2} \mathrm{O}_{2}$ for $24 \mathrm{~h}$ ). As compared to untreated THP-1, the adhesion of TTHP-1 to $\mathrm{H}_{2} \mathrm{O}_{2}$ untreated HUVEC significantly increased while the adhesion of TTHP-1/ UDBMSCS and TTHP-1/TDBMSC to $\mathrm{H}_{2} \mathrm{O}_{2}$ untreated HUVEC significantly reduced after $30 \mathrm{~min}$ (a). As compared to TTHP-1, the adhesion of TTHP-1/ UDBMSCs and TTHP-1/TDBMSC to $\mathrm{H}_{2} \mathrm{O}_{2}$ untreated HUVEC significantly reduced after $30 \mathrm{~min}$ (a). As compared to untreated THP-1, the adhesion of TTHP-1 to $\mathrm{H}_{2} \mathrm{O}_{2}$ pretreated HUVEC was not significantly changed $(P>0.05)$ after 30 min while the adhesion of TTHP-1/UDBMSCS and TTHP-1/ TDBMSC to $\mathrm{H}_{2} \mathrm{O}_{2}$ pretreated HUVEC significantly reduced after 30 min as compared to untreated THP-1 and TTHP-1 (b). Each experiment was performed in triplicate and repeated for five times with five independent preparations of DBMSCs and HUVEC. ${ }^{*} P<0.05$. Bars represent standard errors 
as compared to $\mathrm{H}_{2} \mathrm{O}_{2}$-untreated monocytes (THP-1), and culturing with DBMSCs (TTHP-1 + DBMSC) significantly increased ICAM-1 expression in TTHP-1, $P<0.05$ (Fig. 9a). Similarly, the expression of CD44 in TTHP-1 and TTHP-1 + DBMSC was significantly increased as compared to THP-1 $(P<0.05)$, and there was no difference in CD44 expression between TTHP-1 and TTHP-1 + DBMSC (Fig. 9c). In contrast, the expression of VCAM-1 in TTHP-1was not significantly changed as compared to THP-1 $(P<0.05)$, but the culture with DBMSCs (TTHP-1 + DBMSC) significantly decreased VECAM-1 expression in TTHP-1 (Fig. 9b).

\section{DBMSCs increased the activities of glutathione and thioredoxin reductases in $\mathrm{H}_{2} \mathrm{O}_{2}$-treated HUVEC}

Cells are protected from injury induced by oxidative stress by employing several antioxidant defense mechanisms [14]. To address the possibility that DBMSCs can protect endothelial cells from injury induced by $\mathrm{H}_{2} \mathrm{O}_{2}$, we examined the effect of DBMSCs on the activities of glutathione and thioredoxin reductases (an antioxidant enzyme) in $\mathrm{H}_{2} \mathrm{O}_{2}$-treated endothelial cells.

Glutathione reductase activity in $\mathrm{H}_{2} \mathrm{O}_{2}$-treated HUVEC cultured with CMDMSC, SFDBMSC, and ICDBMSC is significantly higher than $\mathrm{H}_{2} \mathrm{O}_{2}$-treated HUVEC $(P<0.05)$. At baseline, the level of glutathione reductase in HUVEC was $77.5 \mathrm{mU} / \mathrm{mL} \pm 4.87 \mathrm{mU} / \mathrm{mL}$. Exposure of HUVEC to $100 \mu \mathrm{M} \mathrm{H} \mathrm{H}_{2} \mathrm{O}_{2}$ for $48 \mathrm{~h}$, the level of glutathione reductase was $29.50 \pm 2.55$. The level of glutathione reductase levels in $\mathrm{H}_{2} \mathrm{O}_{2}$-treated endothelial cell cultured with CMDBMSC, SFDBMSC, and ICDBMSC were $56.90 \mathrm{mU} / \mathrm{mL} \pm 3.11 \mathrm{mU} /$ $\mathrm{mL}, 62.38 \mathrm{mU} / \mathrm{mL} \pm 3.01 \mathrm{mU} / \mathrm{mL}$, and $65.49 \mathrm{mU} / \mathrm{mL} \pm$ $3.95 \mathrm{mU} / \mathrm{mL}$, respectively. As compared to $\mathrm{H}_{2} \mathrm{O}_{2}$-treated
HUVEC, there were an approximately 1.92-, 2.11-, and 2.22-fold increase in the levels of glutathione reductase in $\mathrm{H}_{2} \mathrm{O}_{2}$-treated HUVEC cultured with CMDMSC, SFDBMSC, and ICDBMSC, respectively, $P<0.05$.

Thioredoxin reductase activity in $\mathrm{H}_{2} \mathrm{O}_{2}$-treated HUVEC cultured with CMDMSC, SFDBMSC, and ICDBMSC is significantly higher than $\mathrm{H}_{2} \mathrm{O}_{2}$-treated HUVEC $(P<0.05)$. At baseline, the activity of thioredoxin reductase was $91.67 \pm 10.14 \mathrm{mU} / 10^{6}$ cell. Exposure of HUVEC to $100 \mu \mathrm{M} \mathrm{H} \mathrm{H}_{2} \mathrm{O}_{2}$ for $48 \mathrm{~h}$, the activity of the enzyme was reduced to $43.33 \pm 10.73 \mathrm{mU} / 10^{6}$ cell. The activity of thioredoxin reductase in $\mathrm{H}_{2} \mathrm{O}_{2}$-treated endothelial cell cultured with CMDBMSC, SFDBMSC, and ICDBMSC was $79.33 \pm 7.21 \mathrm{mU} / 10^{6}$ cell, $88.33 \pm 9.28 \mathrm{mU} / 10^{6}$ cell, and $83.33 \pm 9.28 \mathrm{mU} / 10^{6}$ cell, respectively. As compared to $\mathrm{H}_{2} \mathrm{O}_{2}$-treated HUVEC, there were an approximately 1.83-, 2.03-, and 1.92-fold increase in the activity of thioredoxin reductase in $\mathrm{H}_{2} \mathrm{O}_{2}$-treated HUVEC cultured with CMDBMSC, SFDBMSC, and ICDBMSC, respectively. These data suggest that culturing $\mathrm{H}_{2} \mathrm{O}_{2}$-treated HUVEC with DBMSCs can protect endothelial cells from oxidative stress induced by $\mathrm{H}_{2} \mathrm{O}_{2}$.

\section{DBMSCs modulated the effect of $\mathrm{H}_{2} \mathrm{O}_{2}$ on the expression of genes important in endothelial cell functions}

The expression of genes mediating endothelial cell functions was studied after culturing endothelial cells with $\mathrm{H}_{2} \mathrm{O}_{2}$ in the presence or absence of DBMSCs for $48 \mathrm{~h}$ and then analyzed and assessed using the real-time PCR assay. Results show that DBMSCs modulated $\mathrm{H}_{2} \mathrm{O}_{2}$ effects on endothelial cell expression of genes underlying many of endothelial cell functional activities including survival, apoptosis, injury, fibrosis formation, inflammation,

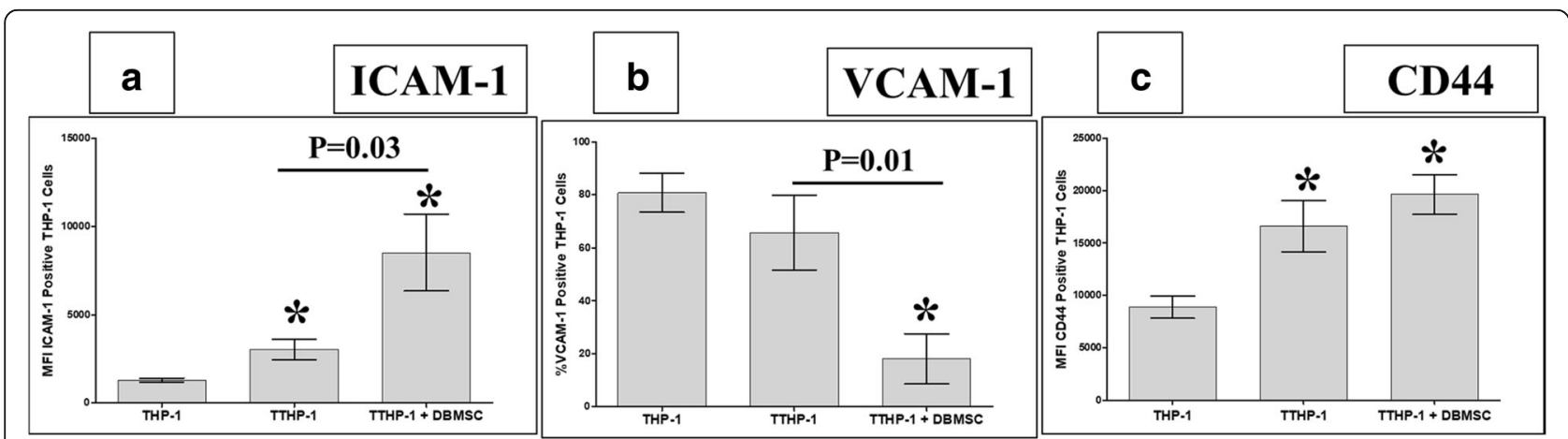

Fig. 9 The flow cytometric analysis of monocytes (THP-1) expression of ICAM-1, VCAM-1, and CD44. THP-1 were initially cultured with $100 \mu M$ $\mathrm{H}_{2} \mathrm{O}_{2}$ (TTHP-1) for $24 \mathrm{~h}$ and then cultured with DBMSCs at 5:1 THP-1:DBMSC ratio (TTHP-1/DBMSC). The flow cytometry was then evaluated after $24 \mathrm{~h}$ culture. The expression of ICAM-1 by TTHP-1 and by TTHP-1/DBMSC significantly increased as compared with $\mathrm{H}_{2} \mathrm{O}_{2}$-untreated THP-1 (a). As compared to TTHP-1, the expression of ICAM-1 by TTHP-1/DBMSC significantly increased (a). As compared with untreated THP-1, TTHP-1 expression of VCAM-1 was not significantly changed $(P>0.05)$ while significantly increased by TTHP-1/DBMSC $(\mathbf{b})$. As compared with TTHP-1, TTHP-1/ DBMSC expression of VCAM-1 significantly increased (b). TTHP-1 and TTHP-1/DBMSC expression of CD44 significantly increased as compared to untreated THP-1 while TTHP-1/DBMSC expression of CD44 was not significantly changed as compared with TTHP-1 (c). Each experiment was performed in triplicate and repeated for five times with five independent preparations of DBMSCs and HUVEC. ${ }^{*} \mathrm{P}<0.05$. Bars represent standard errors 
angiogenesis, permeability, thrombus formation, and leukocyte adhesion as well as infiltration as compared to untreated endothelial cells (Tables 2, 3, 4, 5, and 6).

\section{Discussion}

We previously reported that DBMSCs protect endothelial cell activation by reducing the adhesion of monocytes to endothelial cells and their stimulatory effect on the proliferation of endothelial cells [2, 12]. These two events are the basis of endothelial cell injury in inflammatory diseases, such as atherosclerosis [12]. Inflammatory diseases are also associated with high level of oxidative stress mediators, such as $\mathrm{H}_{2} \mathrm{O}_{2}$ [15-19]. Recently, we reported the ability of DBMSCs to survive

Table 2 DBMSCs modulate the expression of genes involved in endothelial cell (EC) survival, apoptosis, injury, fibrosis formation, and inflammation. THUVEC (HUVEC were cultured with $100 \mu \mathrm{M} \mathrm{H} 2 \mathrm{O} 2$ for $48 \mathrm{~h}$ ). TDBMSC (HUVEC were cultured with DBMSC and $100 \mu \mathrm{M} \mathrm{H}_{2} \mathrm{O}_{2}$ for $48 \mathrm{~h}$ )

\begin{tabular}{|c|c|c|c|c|c|c|}
\hline \# & Gene symbol & Gene full name & $\begin{array}{l}\text { THUVEC mean } \\
\Delta \Delta^{-2} \text { values }\end{array}$ & $\begin{array}{l}\text { TDBMSC Mean } \\
\Delta \Delta^{-2} \text { values }\end{array}$ & $\begin{array}{l}\text { Fold change } \\
\text { (TDBMSC Vs. } \\
\text { THUVEC) } \\
P<0.05\end{array}$ & Biological activities \\
\hline 1 & $\mathrm{BCL} 2$ & B-cell Lymphoma 2 & 2 & 23 & 11.5 -fold $\uparrow$ & \multirow[t]{11}{*}{ Induce EC survival } \\
\hline 2 & EDN1 & Endothelin-1 & 12 & 82 & $>6.64$-fold $\uparrow$ & \\
\hline 3 & EDNRA & Endothelin-1 (ET-1) Receptor A & 3 & 9 & 3-fold $\uparrow$ & \\
\hline 4 & HMOX1 & Heme Oxygenase-1 & 7 & 158 & 20 -fold $\uparrow$ & \\
\hline 5 & KDR & $\begin{array}{l}\text { Vascular Endothelial Growth Factor } \\
\text { Receptor } 3 \text { (VEGFR3) }\end{array}$ & 2 & 52 & 22.57 -fold $\uparrow$ & \\
\hline 6 & MMP2 & Matrix Metallopeptidase 2 & 9 & 36 & 4 -fold $\uparrow$ & \\
\hline 7 & SPHK1 & Sphingosine Kinase 1 & 44 & 840,958 & $\begin{array}{l}19112.68- \\
\text { fold } \uparrow\end{array}$ & \\
\hline 8 & MMP9 & Matrix Metallopeptidase 9 & 1 & 6 & 6-fold $\uparrow$ & \\
\hline 9 & PECAM1 & $\begin{array}{l}\text { Platelet endothelial cell adhesion } \\
\text { molecule }\end{array}$ & 1090 & 7242 & 6.64-fold $\uparrow$ & \\
\hline 10 & TNFSF10 & $\begin{array}{l}\text { TNF-related apoptosis-inducing ligand } \\
\text { (TRAIL) }\end{array}$ & 7 & 30 & $>4.20$-fold $\uparrow$ & \\
\hline 11 & TYMP & Thymidine Phosphorylase & 5 & 27 & $>5$-fold $\uparrow$ & \\
\hline 12 & FAS & Fas cell surface death receptor & 3 & 0.76 & $>3$-fold $\downarrow$ & \multirow[t]{2}{*}{ Induce EC apoptosis } \\
\hline 13 & PF4 & Platelet Factor 4 & 21 & 0.69 & > 30-fold $\downarrow$ & \\
\hline 14 & HIF1a & Hypoxia-Inducible Factor-1a & 159 & 11 & $>14$-fold $\downarrow$ & \multirow[t]{4}{*}{ Induce EC injury } \\
\hline 15 & $\begin{array}{l}\text { SERPINE1 } \\
\text { (PAI-1) }\end{array}$ & Type 1 plasminogen activator inhibitor & 997 & 248 & 4-fold $\downarrow$ & \\
\hline 16 & TIMP1 & TIMP Metallopeptidase Inhibitor 1 & 3 & 1 & 3-fold $\downarrow$ & \\
\hline 17 & ACE & Angiotensin I Converting Enzyme & 15,765 & 5 & 3153-fold $\downarrow$ & \\
\hline 18 & $\mathrm{~F} 2 \mathrm{R}$ & $\begin{array}{l}\text { Coagulation Factor II Thrombin } \\
\text { Receptor }\end{array}$ & 20 & 1 & 20-fold $\downarrow$ & \multirow[t]{4}{*}{ Induce EC inflammation } \\
\hline 19 & ADAM17 & A disintegrin and Metalloprotease 17 & 256 & 4 & 64-fold $\downarrow$ & \\
\hline 20 & FLT1 & $\begin{array}{l}\text { Vascular Endothelial Growth Factor } \\
\text { Receptor } 1\end{array}$ & 23 & 12 & 1.91-fold $\downarrow$ & \\
\hline 21 & TNF-a & Tumor Necrosis Factor- $a$ & 591 & 2 & > 295-fold $\downarrow$ & \\
\hline 22 & PTK2 & $\begin{array}{l}\text { PTK2 protein tyrosine kinase } 2 \text { (PTK2) } \\
\text { or focal adhesion kinase (FAK), }\end{array}$ & 8 & 2 & 4-fold $\downarrow$ & Inhibits inflammation and fibrosis \\
\hline 23 & PLG & Plasminogen & 8 & 90 & $>11$-fold $\uparrow$ & $\begin{array}{l}\text { Inhibits inflammation and, promotes fibrin } \\
\text { clearance }\end{array}$ \\
\hline 24 & F3 & Coagulation Factor III, Tissue Factor & 30 & 0.06 & 500-fold $\downarrow$ & \multirow{2}{*}{$\begin{array}{l}\text { Induces EC injury by induction of fibrin } \\
\text { and thrombus formation }\end{array}$} \\
\hline 25 & THBD & Thrombomodulin & 1013 & 1 & 1013-fold $\downarrow$ & \\
\hline 26 & THBS1 & Thrombospondin 1 (TSP-1) & 1097 & 3 & > 365-fold $\downarrow$ & Induces EC inflammation and injury \\
\hline 27 & TFPI & Tissue Factor Pathway Inhibitor & 11 & 23 & $\sim 2$-fold $\uparrow$ & $\begin{array}{l}\text { Inhibits EC injury by reducing thrombus } \\
\text { formation }\end{array}$ \\
\hline
\end{tabular}


Table 3 DBMSCs modulate the expression of genes mediating endothelial cell (EC) angiogenesis and migration. THUVEC (HUVEC were cultured with $100 \mu \mathrm{M} \mathrm{H} 2 \mathrm{O} 2$ for $48 \mathrm{~h}$ ). TDBMSC (HUVEC were cultured with DBMSC and $100 \mu \mathrm{M} \mathrm{H} \mathrm{H}_{2}$ for 48 h)

\begin{tabular}{|c|c|c|c|c|c|c|}
\hline \# & Gene symbol & Gene full name & $\begin{array}{l}\text { THUVEC mean } \\
\Delta \Delta^{-2} \text { values }\end{array}$ & $\begin{array}{l}\text { TDBMSC mean } \\
\Delta \Delta^{-2} \text { values }\end{array}$ & $\begin{array}{l}\text { Fold change } \\
\text { (TDBMSC Vs. THUVEC) } \\
P<0.05\end{array}$ & Biological activities \\
\hline 1 & CAV1 & Caveolin-1 & 12 & 1472 & $>122$-fold $\uparrow$ & Inhibit EC angiogenesis \\
\hline 2 & WWF & von Willebrand Factor & 4 & 693 & $>173$-fold $\uparrow$ & \\
\hline 3 & AGT & Angiotensinogen & 1 & 1018 & 1018-fold $\uparrow$ & \\
\hline 4 & CASP3 & Caspases 3 & 24 & 177 & $>7$-fold $\uparrow$ & \\
\hline 5 & BAX & Bcl-2-associated X & 4 & 27 & 6.75 -fold $\uparrow$ & \\
\hline 6 & $\mathrm{~F} 2 \mathrm{R}$ & Coagulation Factor II Thrombin Receptor & 20 & 1 & 20-fold $\downarrow$ & Induce EC angiogenesis \\
\hline 7 & FGF1 & Fibroblast Growth Factor 1 & 3384 & 0.12 & 28,200-fold $\downarrow$ & \\
\hline 8 & FGF2 & Fibroblast Growth Factor 2 & 14 & 4 & 3.5 -fold $\downarrow$ & \\
\hline 9 & $\mathrm{KIT}$ & Tyrosine Protein Kinase Kit or CD117 & 122,521 & 0.74 & > 165568-fold $\downarrow$ & \\
\hline 10 & PTGIS & Prostacyclin Synthase & 7 & 2 & 3.5-fold $\downarrow$ & \\
\hline 11 & PTGS2 & Cyclooxygenase (COX) & 15 & 2 & 7.5-fold $\downarrow$ & \\
\hline 12 & SELPLG & P-selectin glycoprotein ligand-1 & 16 & 4 & 4-fold $\downarrow$ & \\
\hline 13 & TEK & EK Receptor Tyrosine Kinase (TIE-2) & 67 & 20 & 3.35-fold $\downarrow$ & \\
\hline 14 & VEGFA & Vascular Endothelial Growth Factor A & 2919 & 0.52 & $>5613$-fold $\downarrow$ & \\
\hline 15 & CFLAR & CASP8 and FADD like apoptosis regulator & 530 & 85 & $>$ 6-fold $\downarrow$ & \\
\hline 16 & EDN1 & Endothelin-1 & 12 & 82 & 6.83-fold $\uparrow$ & Induce EC migration \\
\hline 17 & SPHK1 & Sphingosine Kinase 1 & 44 & 840,958 & 19112.68-fold $\uparrow$ & \\
\hline 18 & HMOX1 & Heme Oxygenase-1 & 7 & 158 & 22.57 -fold $\uparrow$ & \\
\hline
\end{tabular}

and function under the stress of $\mathrm{H}_{2} \mathrm{O}_{2}$ [20]. In addition, DBMSCs inhibit the angiogenesis of endothelial cells in $\mathrm{H}_{2} \mathrm{O}_{2}$ environment [20]. Therefore, DBMSCs have the potential to be used as a cell-based therapy for the treatment of inflammatory diseases. In this study, we investigated the ability of DBMSCs to protect endothelial cell functions from stress induced by both $\mathrm{H}_{2} \mathrm{O}_{2}$ and monocytes.

First, we determined the effect of DBMSCs on endothelial cell function under $\mathrm{H}_{2} \mathrm{O}_{2}$. DBMSCs significantly induced the stimulatory effect of $\mathrm{H}_{2} \mathrm{O}_{2}$ on endothelial cell proliferation (Fig. 3a, b). This contrasts with our recent finding that MSCs from the chorionic villi of human placentae (pMSCs) reverse the proliferative effect of $\mathrm{H}_{2} \mathrm{O}_{2}$ on endothelial cells [13]. This discrepancy can be attributed to the niche of both DBMSCs and pMSCs. During normal pregnancy, DBMSCs are located in the decidua where they are in a continuous exposure to high levels of oxidative stress mediators, because they are in a closed proximity to the maternal vessels $[21,22]$ while

Table 4 DBMSCs modulate the expression of genes mediating endothelial cell (EC) permeability. THUVEC (HUVEC were cultured with $100 \mu \mathrm{M} \mathrm{H} 2 \mathrm{O} 2$ for $48 \mathrm{~h}$ ). TDBMSC (HUVEC were cultured with DBMSC and $100 \mu \mathrm{M} \mathrm{H}_{2} \mathrm{O}_{2}$ for $48 \mathrm{~h}$ )

\begin{tabular}{|c|c|c|c|c|c|c|}
\hline \# & Gene Symbol & Gene full name & $\begin{array}{l}\text { THUVEC Mean } \\
\Delta \Delta^{-2} \text { values }\end{array}$ & $\begin{array}{l}\text { TDBMSC Mean } \\
\Delta \Delta^{-2} \text { values }\end{array}$ & $\begin{array}{l}\text { Fold change } \\
\text { (TDBMSC Vs. } \\
\text { THUVEC) } \\
P<0.05\end{array}$ & $\begin{array}{l}\text { Biological } \\
\text { activities }\end{array}$ \\
\hline 1 & ACE & Angiotensin I Converting Enzyme & 15,765 & 5 & 3153-fold $\downarrow$ & \multirow{5}{*}{$\begin{array}{l}\text { Induce EC } \\
\text { permeability }\end{array}$} \\
\hline 2 & ADAM17 & A disintegrin and Metalloprotease 17 & 256 & 4 & 64-fold $\downarrow$ & \\
\hline 3 & $\| \mathrm{L} 1 \beta$ & Interleukin 1 beta & 4 & 0.46 & 8.69-fold $\downarrow$ & \\
\hline 4 & IL6 & Interleukin 6 & 194 & 59 & $>3$-fold $\downarrow$ & \\
\hline 5 & VEGFA & Vascular Endothelial Growth Factor A & 2919 & 0.52 & $>5613$-fold $\downarrow$ & \\
\hline 6 & CAV1 & Caveolin-1 & 12 & 1472 & $>122$-fold $\uparrow$ & \multirow{2}{*}{$\begin{array}{l}\text { Inhibit EC } \\
\text { permeability }\end{array}$} \\
\hline 7 & NPR1 & $\begin{array}{l}\text { Natriuretic Peptide Receptor A/ Guanylate } \\
\text { Cyclase A (Atrionatriuretic Peptide Receptor A) }\end{array}$ & 1 & 12 & 12-fold $\uparrow$ & \\
\hline
\end{tabular}


Table 5 DBMSCs modulate the expression of genes mediating leukocyte infiltration of endothelial cells (EC), adhesion of inflammatory cells and monocyte adhesion and transmigration. THUVEC (HUVEC were cultured with $100 \mu \mathrm{M} \mathrm{H} 2 \mathrm{O} 2$ for 48 h). TDBMSC (HUVEC were cultured with DBMSC and $100 \mu \mathrm{M} \mathrm{H}_{2} \mathrm{O}_{2}$ for $48 \mathrm{~h}$ )

\begin{tabular}{|c|c|c|c|c|c|c|}
\hline \# & Gene symbol & Gene full name & $\begin{array}{l}\text { THUVEC mean } \\
\Delta \Delta^{-2} \text { values }\end{array}$ & $\begin{array}{l}\text { TDBMSC mean } \\
\Delta \Delta^{-2} \text { values }\end{array}$ & $\begin{array}{l}\text { Fold change } \\
\text { (TDBMSC Vs. THUVEC) } \\
P<0.05\end{array}$ & Biological activities \\
\hline 1 & $\mathrm{CDH} 5$ & $\begin{array}{l}\text { VE-Cadherin (Vascular Endothelial } \\
\text { Cadherin) }\end{array}$ & 61 & 3 & $\sim 20$-fold $\downarrow$ & Induce leukocyte infiltration \\
\hline 2 & SELE & E- selectin & 21 & 1 & 21-fold $\downarrow$ & \\
\hline 3 & VCAM1 & Vascular Cell Adhesion Molecule 1 & 7 & 0.26 & 26.92-fold $\downarrow$ & \\
\hline 4 & PLG & Plasminogen & 8 & 90 & $\sim 11$-fold $\uparrow$ & $\begin{array}{l}\text { Inhibits adhesion of inflammatory } \\
\text { cells }\end{array}$ \\
\hline 5 & THBS1 & Thrombospondin 1 (TSP-1) & 1097 & 3 & $>365$-fold $\downarrow$ & $\begin{array}{l}\text { Induces monocyte adhesion and } \\
\text { transmigration }\end{array}$ \\
\hline
\end{tabular}

Table 6 DBMSCs effects on genes involved in endothelial cell (EC) biology. THUVEC (HUVEC were cultured with $100 \mu \mathrm{M}$ H2O2 for 48 h). TDBMSC (HUVEC were cultured with DBMSC and $100 \mu \mathrm{M} \mathrm{H}_{2} \mathrm{O}_{2}$ for $48 \mathrm{~h}$ )

\begin{tabular}{|c|c|c|c|c|c|}
\hline \# & Gene symbol & Gene full name & $\begin{array}{l}\text { THUVEC mean } \\
\Delta \Delta^{-2} \text { values }\end{array}$ & $\begin{array}{l}\text { TDBMSC mean } \\
\Delta \Delta^{-2} \text { values }\end{array}$ & $\begin{array}{l}\text { Fold change (TDBMSC Vs. THUVEC) } \\
P<0.05\end{array}$ \\
\hline 1 & ANGPT1 & Angiopoietin 1 & 1.35 & 0.64 & Fold change is not statically significant, $P>0.05$ \\
\hline 2 & AGTR1 & Angiotensin II Receptor Type 1 & 0.13 & 0.05 & \\
\hline 3 & ALOX5 & Arachidonate 5-Lipoxygenase & 0.61 & 0.36 & \\
\hline 4 & ANXA5 & Annexin A5 & 9 & 5 & \\
\hline 5 & APOE & Apolipoprotein E & 0.01 & 0.01 & \\
\hline 6 & BCL2L1 & $\mathrm{BCL} 2 \mathrm{~L} 1$ & 11 & 10 & \\
\hline 7 & CALCA & Calcitonin Related Polypeptide Alpha & 0.71 & 0.70 & \\
\hline 8 & CCL2 & C-C motif chemokine ligand 2 & 1 & 0.39 & \\
\hline 9 & CX3CL1 & C-X3-C Motif Chemokine Ligand 1 & 0.50 & 0.34 & \\
\hline 10 & EDN2 & Endothelin 2 & 0.01 & 0.01 & \\
\hline 11 & FASLG & Fas Ligand & 0.39 & 2.54 & \\
\hline 12 & FN1 & Fibronectin 1 & 0.06 & 0.04 & \\
\hline 13 & ICAM1 & Intercellular Adhesion Molecule 1 & 1 & 0.30 & \\
\hline 14 & IL3 & Interleukin 3 & 0.66 & 1.47 & \\
\hline 15 & IL7 & Interleukin 7 & 0.10 & 2.81 & \\
\hline 16 & KLK3 & Kallikrein Related Peptidase 3 & 1 & 2 & \\
\hline 17 & MMP1 & Matrix Metallopeptidase 1 & 3 & 3 & \\
\hline 18 & NOS3 & Nitric Oxide Synthase 3 & 1 & 0.92 & \\
\hline 19 & NPPB & Natriuretic Peptide B & 0.80 & 0.32 & \\
\hline 20 & OCLN & Occludin & 4.99 & 1.48 & \\
\hline 21 & PDGFRA & Platelet Derived Growth Factor Receptor Alpha & 1.06 & 0.26 & \\
\hline 22 & PGF & Placental Growth Factor & 1.40 & 2.96 & \\
\hline 23 & PLAT & Plasminogen Activator, Tissue Type & 3.73 & 0.34 & \\
\hline 24 & PLAU & Plasminogen Activator, Urokinase & 1.59 & 2 & \\
\hline 25 & SELL & Selectin L & 0.16 & 0.09 & \\
\hline 26 & SOD1 & Superoxide Dismutase 1 & 17 & 17 & \\
\hline 27 & TGFB1 & Transforming Growth Factor Beta 1 & 9 & 7 & \\
\hline 28 & ENG & Endoglin & 19 & 16 & \\
\hline
\end{tabular}


pMSCs are usually exposed to a lower levels of oxidative stress mediators because they are in a continuous contact with the fetal circulation $[6,7]$. Therefore, DBMSCs have possibly acquired characteristics similar to $\mathrm{H}_{2} \mathrm{O}_{2}$ on the functions of endothelial cells.

Next, we demonstrated that the stimulatory effects of DBMSCs and $\mathrm{H}_{2} \mathrm{O}_{2}$ on endothelial cell proliferation are reversible (Fig. 4). However, the paracrine communication between DBMSCs and endothelial cells in the presence of $\mathrm{H}_{2} \mathrm{O}_{2}$ showed more stimulatory effect on endothelial cell proliferation than CMDBMSC (molecules produced by unstimulated DBMSCs) and ICDBMSC (intercellular direct contact), Fig. 4 b, c. We also showed that DBMSCs may protect endothelial cells from oxidative stress by the finding that DBMSCs can induce the expression of many genes mediating the survival of endothelial cells and can also reduce the expression of genes that trigger apoptosis, injury, and inflammation in endothelial cells (Table 2) [23-48]. This protective role for DBMSCs on endothelial cells from stress induced by $\mathrm{H}_{2} \mathrm{O}_{2}$ is further confirmed by the ability of DBMSCs to increase the activities of glutathione and thioredoxin reductases (antioxidant enzymes) in $\mathrm{H}_{2} \mathrm{O}_{2}$-treated endothelial cells. Therefore, DBMSCs can protect endothelial cells from stress induced by $\mathrm{H}_{2} \mathrm{O}_{2}$, therefore suggesting a therapeutic potential for DBMSCs in inflammatory diseases.

We also found that ICDBMSC can reduce the stimulatory effect of $\mathrm{H}_{2} \mathrm{O}_{2}$ on endothelial cell adhesion (Fig. 5). In contrast, CMDBMSC and SFDBMSC could not reverse the stimulatory effect of $\mathrm{H}_{2} \mathrm{O}_{2}$ on endothelial cell adhesion (Fig. 5). Instead, SFDBMSC induced the stimulatory effect of $\mathrm{H}_{2} \mathrm{O}_{2}$ on the adhesiveness of endothelial cells. $\mathrm{H}_{2} \mathrm{O}_{2}$ is known to increase the adhesiveness property of endothelial cells through ICAM-1 and VCAM-1 [49-52]. DBMSCs secrete IL-1 $\beta$ and IL-10 [2]. IL-1 $\beta$ is a proinflammatory cytokine that induces endothelial cell production of $\mathrm{H}_{2} \mathrm{O}_{2}$ while IL-10 is an anti-inflammatory cytokine that reduces endothelial cell production of $\mathrm{H}_{2} \mathrm{O}_{2}[53,54]$. This may explain why DBMSCs exert dual functions on endothelial cell adhesion depending on the nature of DBMSC treatment. Therefore, paracrine communication with endothelial cells may stimulate DBMSC production of IL1- $\beta$ while the intercellular direct contact with endothelial cells may stimulate DBMSC production of IL-10. The interaction with DBMSCs (ICDBMSC) reduced endothelial cell expression of VCAM (Table 5), thus suggesting that VCAM may mediate the anti-adhesive effect of DBMSC on endothelial cells. Our data highlight that DBMSCs have dual effects "a double-edged sword" on endothelial cells as it was previously reported for the immunomodulatory properties of bone marrow-derived MSCs [55]. However, a future study is essential to reveal this mechanism.

DBMSCs show also dual effects on endothelial cell migration. DBMSCs (SFDBMSC and ICDBMSC) reversed the inhibitory effect of $\mathrm{H}_{2} \mathrm{O}_{2}$ on endothelial cell migration while CMDBMSC enhanced the inhibitory effect of $\mathrm{H}_{2} \mathrm{O}_{2}$ on the migration of endothelial cells (Fig. 6). In this study, we found that DBMSCs induced the expression of a number of genes (e.g., endothelin-1, sphingosine kinase 1, and heme oxygenase-1) by $\mathrm{H}_{2} \mathrm{O}_{2}$-treated endothelial cells. These genes mediate the migration of endothelial cells [56-58], thus suggesting that these genes may mediate the stimulatory effect of DBMSCs on endothelial cell migration.

Adhesion and migration are the early steps towards endothelial cell angiogenesis [12]. Recently, we showed that DBMSCs inhibit $\mathrm{H}_{2} \mathrm{O}_{2}$-treated endothelial cell angiogenesis [20]. In this study, we found that DBMSCs increased and decreased $\mathrm{H}_{2} \mathrm{O}_{2}$-treated endothelial cell expression of various antiangiogenic [25, 59-63] and proangiogenic $[24,39,64-70]$ genes, respectively (Table 3). These data suggest that these genes may mediate DBMSC inhibitory effect on endothelial cell angiogenesis. However, future functional studies are essential to elucidate the roles of these genes in the antiangiogenic properties of DBMSCs.

We previously reported that DBMSCs have an inhibitory effect on monocyte induction of endothelial cell proliferation and on their adhesion to endothelial cells [12]. In this study, we also show that in the presence of $\mathrm{H}_{2} \mathrm{O}_{2}$, DBMSCs inhibit the adhesion of monocytes to endothelial cells (Fig. 8) and also inhibit endothelial cell proliferation (Fig. 7b). This further confirms the protective role of DBMSCs on endothelial cells proliferation (discussed above) from oxidative stress. These data indicate that DBMSCs have the ability to reduced endothelial cell proliferation, a pathological phenomenon that is known to contribute to the formation of atheroma plaque in atherosclerosis [71].

DBMSCs reduced monocyte expression of VCAM-1 (Fig. 9b), thus indicating that this adhesion molecule may mediate monocyte adhesion to endothelial cells. We also found that DBMSCs modulated $\mathrm{H}_{2} \mathrm{O}_{2}$-treated endothelial cell expression of various genes mediating endothelial cell proliferation, adhesion [44, 45], and permeability $[38,40,59,69,72-74]$ as well as monocyte infiltration of endothelial cells $[44,75,76]$. Together, these data demonstrate the protective roles that DBMSCs may exert on endothelial cells via mechanisms may involve genes listed in Tables 2, 3, 4, and 5. However, functional studies are necessary to elucidate the effects of these genes in mediating DBMCs protective activities on endothelial cells.

\section{Conclusions}

This is the first comprehensive study to demonstrate the protective role of DBMSCs on endothelial cells in harsh 
oxidative stress environment. DBMSCs can protect endothelial cells from injury induced by oxidative stress or immune cells. Endothelial cell injury is a hallmark of inflammatory diseases, such as atherosclerosis where endothelial cells show increased functional activities (proliferation, adhesion, migration, angiogenesis, and permeability) and increased fibrin and thrombus formation as well as increased adhesion to immune cells, such as monocytes and their infiltration. These functional activities could be therapeutical targets for DBMSCs to repair endothelial cell injury and treat atherosclerosis.

\section{Acknowledgements}

We appreciate the staff and patients of the Delivery Unit, King Abdul Aziz Medical City for giving us placentae.

\section{Funding}

This study was supported by grants from KAIMRC (Grant No. RC12/133)

\section{Availability of data and materials}

All data generated during this study are included in this published article.

\begin{abstract}
Authors' contributions
MHA proposed and supervised the project. MHA designed the experiments. MAA performed the experiments. MHA, MAA, and TK analyzed the data. MHA wrote the manuscript. MHA, FMA, TK, BK, SAM, RK, AOA, and ASA contributed to the data analysis and interpretation of results. All authors reviewed the manuscript. All authors read and approved the final manuscript.
\end{abstract}

\section{Ethics approval and consent to participate}

The institutional review board (IRB) at King Abdulla International Medical Research Centre (KAIMRC), Saudi Arabia, approved this study. Samples (placentae and umbilical cords of uncomplicated human pregnancies, 38-40 gestational weeks) were obtained and used immediately after signing consent forms.

\section{Consent for publication}

"Not applicable". All authors agree to publish this manuscript.

\section{Competing interests}

The authors declare that they have no competing interests.

\section{Publisher's Note}

Springer Nature remains neutral with regard to jurisdictional claims in published maps and institutional affiliations.

\footnotetext{
Author details

${ }^{1}$ National Center for Stem Cell Technology, Life Sciences and Environment Research Institute, King Abdulaziz City for Science and Technology, P.O Box 6086, Riyadh 11442, Kingdom of Saudi Arabia. ${ }^{2}$ Stem Cells and Regenerative Medicine Department, King Abdullah International Medical Research Center, King Abdulaziz Medical City, Ministry of National Guard Health Affairs, Mail Code 1515, P.O. Box 22490, Riyadh 11426, Saudi Arabia. ${ }^{3}$ Division of Obstetrics and Gynecology, Department of Clinical Science, Intervention and Technology, Karolinska Institutet, 14186 Stockholm, Sweden. ${ }^{4}$ Center for Hematology and Regenerative Medicine, Karolinska Institutet, 14186 Stockholm, Sweden. ${ }^{5}$ College of Medicine, King Saud Bin Abdulaziz University for Health Sciences, King Abdulaziz Medical City, Ministry of National Guard Health Affairs, Mail Code 3124, P.O. Box 3660, Riyadh 11481, Saudi Arabia. ${ }^{6}$ Adult Hematology and Stem Cell Transplantation, King Abdulaziz Medical City, Ministry of National Guard Health Affairs, Mail Code 1515, P.O. Box 22490, Riyadh 11426, Saudi Arabia. ${ }^{7}$ Department of Maternal-Fetal Medicine Pregnancy Research Centre, University of Melbourne, Melbourne, Australia. ${ }^{8}$ Department of Obstetrics and Gynaecology, Royal Women's Hospital, Parkville, Melbourne, Victoria 3052, Australia. ${ }^{9}$ Department of Forensic Biology, College of Forensic Sciences, Naif
}

Arab University for Security Sciences, Riyadh, Saudi Arabia. ${ }^{10}$ College of Science and Health Professions, King Saud Bin Abdulaziz University for Health Sciences, King Abdulaziz Medical City, Ministry of National Guard Health Affairs, Mail Code 3124, P.O. Box 3660, Riyadh 11481, Saudi Arabia.

Received: 28 May 2018 Revised: 17 September 2018

Accepted: 28 September 2018 Published online: 25 October 2018

\section{References}

1. Abumaree MH, Abomaray FM, Alshabibi MA, AlAskar AS, Kalionis B. Immunomodulatory properties of human placental mesenchymal stem stromal cells. Placenta. 2017;59:87-95. https://doi.org/10.1016/j.placenta. 2017.04.003. PubMed PMID: 28411943.

2. Abomaray FM, Al Jumah MA, Alsaad KO, Jawdat D, Al Khaldi A, AlAskar AS, et al. Phenotypic and functional characterization of mesenchymal stem/ multipotent stromal cells from decidua basalis of human term placenta. Stem Cells Int. 2016;2016:5184601. https://doi.org/10.1155/2016/5184601 PubMed PMID: 27087815; PubMed Central PMCID: PMCPMC4764756.

3. Kanasaki K, Kalluri R. The biology of preeclampsia. Kidney Int. 2009;76(8): 831-7. https://doi.org/10.1038/ki.2009.284 PubMed PMID: 19657323; PubMed Central PMCID: PMCPMC4313558.

4. Huang YC, Yang ZM, Chen XH, Tan MY, Wang J, Li XQ, et al. Isolation of mesenchymal stem cells from human placental decidua basalis and resistance to hypoxia and serum deprivation. Stem Cell Rev. 2009:5(3):24755. https://doi.org/10.1007/s12015-009-9069-x PubMed PMID: 19590988.

5. Abumaree MH, Al Jumah MA, Kalionis B, Jawdat D, Al Khaldi A, AlTalabani $A A$, et al. Phenotypic and functional characterization of mesenchymal stem cells from chorionic villi of human term placenta. Stem Cell Rev. 2013;9(1): 16-31. https://doi.org/10.1007/s12015-012-9385-4 PubMed PMID: 22628114.

6. Braekke K, Harsem NK, Staff AC. Oxidative stress and antioxidant status in fetal circulation in preeclampsia. Pediatr Res. 2006;60(5):560-4. https://doi. org/10.1203/01.pdr.0000242299.01219.6a PubMed PMID: 16988193.

7. Kusuma GD, Abumaree MH, Pertile MD, Perkins AV, Brennecke SP, Kalionis B. Mesenchymal stem/stromal cells derived from a reproductive tissue niche under oxidative stress have high aldehyde dehydrogenase activity. Stem Cell Rev 2016;12(3):285-297. https://doi.org/10.1007/s12015-016-9649-5. PubMed PMID: 26880140.

8. Davignon J, Ganz P. Role of endothelial dysfunction in atherosclerosis. Circulation. 2004;109(23 Suppl 1):III27-32. https://doi.org/10.1161/01.CIR. 0000131515.03336.f8 PubMed PMID: 15198963.

9. Martindale JL, Holbrook NJ. Cellular response to oxidative stress: signaling for suicide and survival. J Cell Physiol. 2002;192(1):1-15. https://doi.org/10. 1002/jcp.10119 PubMed PMID: 12115731.

10. Shono T, Ono M, Izumi H, Jimi Sl, Matsushima K, Okamoto T, et al. Involvement of the transcription factor NF-kappaB in tubular morphogenesis of human microvascular endothelial cells by oxidative stress. Mol Cell Biol. 1996;16(8):4231-9 PubMed PMID: 8754823; PubMed Central PMCID: PMCPMC231421.

11. Libby P. Inflammation in atherosclerosis. Nature. 2002;420(6917):868-74. https://doi.org/10.1038/nature01323 PubMed PMID: 12490960.

12. Alshabibi MA, Al Huqail AJ, Khatlani T, Abomaray FM, Alaskar AS, Alawad $\mathrm{AO}$, et al. Mesenchymal stem/multipotent stromal cells from human decidua basalis reduce endothelial cell activation. Stem Cells Dev. 2017; 26(18):1355-73. https://doi.org/10.1089/scd.2017.0096. PubMed PMID: 28679316.

13. Abumaree MH, Hakami M, Abomaray FM, Alshabibi MA, Kalionis B, Al Jumah MA, et al. Human chorionic villous mesenchymal stem/stromal cells modify the effects of oxidative stress on endothelial cell functions. Placenta. 2017; 59:74-86. https://doi.org/10.1016/.placenta.2017.05.001. PubMed PMID: 28502524.

14. Sies H. Oxidative stress: from basic research to clinical application. Am J Med 1991;91(3C):31S-38S. PubMed PMID: 1928209.

15. Valle-Prieto A, Conget PA. Human mesenchymal stem cells efficiently manage oxidative stress. Stem Cells Dev. 2010;19(12):1885-93. https://doi. org/10.1089/scd.2010.0093. PubMed PMID: 20380515.

16. Lodi D, lannitti T, Palmieri B. Stem cells in clinical practice: applications and warnings. J Exp Clin Cancer Res : CR. 2011;30:9. https://doi.org/10.1186/ 1756-9966-30-9. PubMed PMID: 21241480; PubMed Central PMCID: PMC3033847.

17. Mimeault M, Batra SK. Concise review: recent advances on the significance of stem cells in tissue regeneration and cancer therapies. Stem Cells. 2006; 
24(11):2319-45. https://doi.org/10.1634/stemcells.2006-0066. PubMed PMID: 16794264.

18. Gattazzo F, Urciuolo A, Bonaldo P. Extracellular matrix: a dynamic microenvironment for stem cell niche. Biochim Biophys Acta. 2014;1840(8): 2506-19. https://doi.org/10.1016/j.bbagen.2014.01.010. PubMed PMID: 24418517; PubMed Central PMCID: PMCPMC4081568.

19. Auletta JJ, Cooke KR, Solchaga LA, Deans RJ, van't Hof W. Regenerative stromal cell therapy in allogeneic hematopoietic stem cell transplantation: current impact and future directions. Biol Blood Marrow Transplant. 2010; 16(7):891-906. https://doi.org/10.1016/j.bbmt.2009.12.005. PubMed PMID: 20018250; PubMed Central PMCID: PMCPMC4155485.

20. Khatlani T, Algudiri D, Alenzi R, Al Subayyil AM, Abomaray FM, Bahattab E, AS AA, Kalionis B, El-Muzaini MF, Abumaree MH. Preconditioning by hydrogen peroxide enhances multiple properties of human decidua basalis mesenchymal stem/multipotent stromal cells. Stem Cells International. 2018: 2018. https://doi.org/10.1155/2018/6480793.

21. Raijmakers MT, Roes EM, Poston L, Steegers EA, Peters WH. The transient increase of oxidative stress during normal pregnancy is higher and persists after delivery in women with pre-eclampsia. Eur J Obstet Gynecol Reprod Biol. 2008;138(1):39-44. https://doi.org/10.1016/j.ejogrb.2007.08.005. PubMed PMID: 17826887

22. Burton GJ, Jauniaux E. Oxidative stress. Best practice \& research Clinical obstetrics \& gynaecology. 2011;25(3):287-99. https://doi.org/10.1016/j. bpobgyn.2010.10.016. PubMed PMID: 21130690; PubMed Central PMCID: PMC3101336.

23. Dong F, Zhang X, Wold LE, Ren Q, Zhang Z, Ren J. Endothelin-1 enhances oxidative stress, cell proliferation and reduces apoptosis in human umbilical vein endothelial cells: role of ETB receptor, NADPH oxidase and caveolin-1. Br Aust J Pharm 2005;145(3):323-33. https://doi.org/10.1038/sj.bjp.0706193. PubMed PMID: 15765100; PubMed Central PMCID: PMCPMC1576147.

24. Gao C, Sun W, Christofidou-Solomidou M, Sawada M, Newman DK, Bergom C, et al. PECAM-1 functions as a specific and potent inhibitor of mitochondrial-dependent apoptosis. Blood. 2003;102(1):169-79. https://doi. org/10.1182/blood-2003-01-0003. PubMed PMID: 12649141.

25. Kern TS, Du Y, Miller CM, Hatala DA, Levin LA. Overexpression of BCl-2 in vascular endothelium inhibits the microvascular lesions of diabetic retinopathy. Am J Pathol. 2010;176(5):2550-8. https://doi.org/10.2353/ajpath.2010.091062. PubMed PMID: 20363911: PubMed Central PMCID: PMCPMC2861119.

26. Kinderlerer AR, Pombo Gregoire I, Hamdulay SS, Ali F, Steinberg R, Silva G, et al. Heme oxygenase-1 expression enhances vascular endothelial resistance to complement-mediated injury through induction of decayaccelerating factor: a role for increased bilirubin and ferritin. Blood 2009; 113(7):1598-607. https://doi.org/10.1182/blood-2008-04-152934. PubMed PMID: 19036700

27. Kwon YG, Min JK, Kim KM, Lee DJ, Billiar TR, Kim YM. Sphingosine 1-phosphate protects human umbilical vein endothelial cells from serum-deprived apoptosis by nitric oxide production. J Biol Chem. 2001;276(14):10627-33. https://doi.org/10.1074/jbc.M011449200. PubMed PMID: 11134047.

28. Li A, Dubey S, Varney ML, Dave BJ, Singh RK. IL-8 directly enhanced endothelial cell survival, proliferation, and matrix metalloproteinases production and regulated angiogenesis. J Immunol. 2003;170(6):3369-76. PubMed PMID: 12626597.

29. Liang P, Cheng SH, Cheng CK, Lau KM, Lin SY, Chow EY, et al. Platelet factor 4 induces cell apoptosis by inhibition of STAT3 via up-regulation of SOCS3 expression in multiple myeloma. Haematologica. 2013;98(2):288-95. https:// doi.org/10.3324/haematol.2012.065607. PubMed PMID: 22929979; PubMed Central PMCID: PMCPMC3561438

30. Mikhail M, Vachon PH, D'Orleans-Juste P, Jacques D, Bkaily G. Role of endothelin-1 and its receptors, ETA and ETB, in the survival of human vascular endothelial cells. Can J Physiol Pharmacol. 2017;95(10):1298-305. https://doi.org/10.1139/cjpp-2017-0412. PubMed PMID: 28732172.

31. Toi M, Atiqur Rahman M, Bando H, Chow LW. Thymidine phosphorylase (platelet-derived endothelial-cell growth factor) in cancer biology and treatment. Lancet Oncol. 2005;6(3):158-66. https://doi.org/10.1016/S14702045(05)01766-3. PubMed PMID: 15737832.

32. Wang JF, Zhang X, Groopman JE. Activation of vascular endothelial growth factor receptor- 3 and its downstream signaling promote cell survival under oxidative stress. J Biol Chem. 2004;279(26):27088-97. https://doi.org/10.1074/ jbc.M314015200. PubMed PMID: 15102829.

33. Secchiero P, Gonelli A, Carnevale E, Milani D, Pandolfi A, Zella D, et al. TRAIL promotes the survival and proliferation of primary human vascular endothelial cells by activating the Akt and ERK pathways. Circulation. 2003; 107(17):2250-6. https://doi.org/10.1161/01.CIR.0000062702.60708.C4 PubMed PMID: 12668516

34. Suhara T, Fukuo K, Sugimoto T, Morimoto S, Nakahashi T, Hata S, et al. Hydrogen peroxide induces up-regulation of Fas in human endothelial cells. J Immunol. 1998;160(8):4042-7. PubMed PMID: 9558114.

35. Lee S, Chung J, Ha IS, Yi K, Lee JE, Kang HG, et al. Hydrogen peroxide increases human leukocyte adhesion to porcine aortic endothelial cells via NFkappaB-dependent up-regulation of VCAM-1. Int Immunol. 2007;19(12): 1349-59. https://doi.org/10.1093/intimm/dxm104. PubMed PMID: 17977815.

36. Brodsky SV, Malinowski K, Golightly M, Jesty J, Goligorsky MS. Plasminogen activator inhibitor-1 promotes formation of endothelial microparticles with procoagulant potential. Circulation. 2002;106(18):2372-8. PubMed PMID: 12403669 .

37. Moore R, Hawley A, Sigler R, Farris D, Wrobleski S, Ramacciotti E, et al. Tissue inhibitor of metalloproteinase-1 is an early marker of acute endothelial dysfunction in a rodent model of venous oxidative injury. Ann Vasc Surg. 2009:23(4):498-505. https://doi.org/10.1016/.javsg.2009.03.005. PubMed PMID: 19467832.

38. Mu X, He K, Sun H, Zhou X, Chang L, Li X, et al. Hydrogen peroxide induces overexpression of angiotensin-converting enzyme in human umbilical vein endothelial cells. Free Radic Res. 2013;47(2):116-22. https://doi.org/10.3109/ 10715762.2012.749987. PubMed PMID: 23153326.

39. Kaplanski G, Fabrigoule M, Boulay V, Dinarello CA, Bongrand P, Kaplanski S, et al. Thrombin induces endothelial type II activation in vitro: IL-1 and TNFalpha-independent IL-8 secretion and E-selectin expression. J Immunol. 1997;158(11):5435-41. PubMed PMID: 9164965.

40. Dreymueller D, Martin C, Kogel T, Pruessmeyer J, Hess FM, Horiuchi K, et al. Lung endothelial ADAM17 regulates the acute inflammatory response to lipopolysaccharide. EMBO Mol Med. 2012;4(5):412-23. https://doi.org/10. 1002/emmm.201200217. PubMed PMID: 22367719; PubMed Central PMCID: PMCPMC3403298

41. Shibuya M. Vascular endothelial growth factor receptor-1 (VEGFR-1/Flt1): a dual regulator for angiogenesis. Angiogenesis 2006;9(4):225-30; discussion 31. https://doi.org/10.1007/s10456-006-9055-8. PubMed PMID: 17109193.

42. Valen G, Erl W, Eriksson P, Wuttge D, Paulsson G, Hansson GK. Hydrogen peroxide induces mRNA for tumour necrosis factor alpha in human endothelial cells. Free Radic Res. 1999;31(6):503-12. PubMed PMID: 10630674

43. Sharma R, Colarusso P, Zhang H, Stevens KM, Patel KD. FRNK negatively regulates IL-4-mediated inflammation. J Cell Sci. 2015;128(4):695-705. https://doi.org/10.1242/jcs.156588. PubMed PMID: 25501808.

44. Liu Z, Morgan S, Ren J, Wang Q, Annis DS, Mosher DF, et al. Thrombospondin-1 (TSP1) contributes to the development of vascular inflammation by regulating monocytic cell motility in mouse models of abdominal aortic aneurysm. Circ Res. 2015;117(2):129-41. https://doi.org/10. 1161/CIRCRESAHA.117.305262. PubMed PMID: 25940549; PubMed Central PMCID: PMCPMC4490953.

45. Xiao Q, Danton MJ, Witte DP, Kowala MC, Valentine MT, Bugge TH, et al. Plasminogen deficiency accelerates vessel wall disease in mice predisposed to atherosclerosis. Proc Natl Acad Sci U S A. 1997:94(19):10335-40. PubMed PMID: 9294211; PubMed Central PMCID: PMCPMC23363.

46. Steffel J, Luscher TF, Tanner FC. Tissue factor in cardiovascular diseases: molecular mechanisms and clinical implications. Circulation. 2006;113(5): 722-31. https://doi.org/10.1161/CIRCULATIONAHA.105.567297. PubMed PMID: 16461845.

47. Boehme MW, Galle P, Stremmel W. Kinetics of thrombomodulin release and endothelial cell injury by neutrophil-derived proteases and oxygen radicals. Immunology. 2002;107(3):340-9. PubMed PMID: 12423310; PubMed Central PMCID: PMCPMC1782804.

48. Westrick RJ, Bodary PF, Xu Z, Shen YC, Broze GJ, Eitzman DT. Deficiency of tissue factor pathway inhibitor promotes atherosclerosis and thrombosis in mice. Circulation. 2001;103(25):3044-6. PubMed PMID: 11425765.

49. Bradley JR, Johnson DR, Pober JS. Endothelial activation by hydrogen peroxide. Selective increases of intercellular adhesion molecule-1 and major histocompatibility complex class I. Am J Pathol. 1993;142(5):1598-609. PubMed PMID: 8098585; PubMed Central PMCID: PMCPMC1886909.

50. Lo SK, Janakidevi K, Lai L, Malik AB. Hydrogen peroxide-induced increase in endothelial adhesiveness is dependent on ICAM-1 activation. Am J Phys 1993;264(4 Pt 1):L406-L412. https://doi.org/10.1152/ajplung.1993.264.4.L406. PubMed PMID: 7682787. 
51. Lakshminarayanan V, Beno DW, Costa RH, Roebuck KA. Differential regulation of interleukin-8 and intercellular adhesion molecule- 1 by $\mathrm{H}_{2} \mathrm{O} 2$ and tumor necrosis factor-alpha in endothelial and epithelial cells. J Biol Chem. 1997:272(52):32910-8. PubMed PMID: 9407069.

52. Mendoza L, Carrascal T, De Luca M, Fuentes AM, Salado C, Blanco J, et al. Hydrogen peroxide mediates vascular cell adhesion molecule-1 expression from interleukin-18-activated hepatic sinusoidal endothelium: implications for circulating cancer cell arrest in the murine liver. Hepatology. 2001;34(2): 298-310. https://doi.org/10.1053/jhep.2001.26629. PubMed PMID: 11481615.

53. Anasagasti MJ, Alvarez A, Avivi C, Vidal-Vanaclocha F. Interleukin-1-mediated $\mathrm{H} 2 \mathrm{O} 2$ production by hepatic sinusoidal endothelium in response to B16 melanoma cell adhesion. J Cell Physiol. 1996;167(2):314-23. https://doi.org/ 10.1002/(SICI)1097-4652(199605)167:2<314::AID-JCP16>3.0.CO;2-7. PubMed PMID: 8613473.

54. Shao Y, Cheng Z, Li X, Chernaya V, Wang H, Yang XF. Immunosuppressive/ anti-inflammatory cytokines directly and indirectly inhibit endothelial dysfunction--a novel mechanism for maintaining vascular function. J Hematol Oncol. 2014;7:80. https://doi.org/10.1186/s13045-014-0080-6. PubMed PMID: 25387998; PubMed Central PMCID: PMCPMC4236671.

55. Li W, Ren G, Huang Y, Su J, Han Y, Li J, et al. Mesenchymal stem cells: a double-edged sword in regulating immune responses. Cell Death Differ. 2012;19(9):1505-13. https://doi.org/10.1038/cdd.2012.26. PubMed PMID: 22421969; PubMed Central PMCID: PMCPMC3422473.

56. Paik JH, Chae S, Lee MJ, Thangada S, Hla T. Sphingosine 1-phosphateinduced endothelial cell migration requires the expression of EDG-1 and EDG-3 receptors and Rho-dependent activation of alpha vbeta3- and beta1containing integrins. J Biol Chem. 2001;276(15):11830-7. https://doi.org/10. 1074/jbc.M009422200. PubMed PMID: 11150298.

57. Deshane J, Chen S, Caballero S, Grochot-Przeczek A, Was H, Li Calzi S, et al. Stromal cell-derived factor 1 promotes angiogenesis via a heme oxygenase 1-dependent mechanism. J Exp Med. 2007;204(3):605-18. https://doi.org/10. 1084/jem.20061609. PubMed PMID: 17339405; PubMed Central PMCID: PMCPMC1855437.

58. Daher Z, Noel J, Claing A. Endothelin-1 promotes migration of endothelial cells through the activation of ARF6 and the regulation of FAK activity. Cell Signal. 2008;20(12):2256-65. https://doi.org/10.1016/j.cellsig.2008.08.021. PubMed PMID: 18814847

59. Bauer PM, Yu J, Chen Y, Hickey R, Bernatchez PN, Looft-Wilson R, et al. Endothelial-specific expression of caveolin-1 impairs microvascular permeability and angiogenesis. Proc Natl Acad Sci U S A. 2005;102(1):204-9. https://doi.org/10.1073/pnas.0406092102. PubMed PMID: 15615855; PubMed Central PMCID: PMCPMC544041.

60. Starke RD, Ferraro F, Paschalaki KE, Dryden NH, McKinnon TA, Sutton RE, et al. Endothelial von Willebrand factor regulates angiogenesis. Blood. 2011; 117(3):1071-80. https://doi.org/10.1182/blood-2010-01-264507. PubMed PMID: 21048155; PubMed Central PMCID: PMCPMC3035068.

61. Celerier J, Cruz A, Lamande N, Gasc JM, Corvol P. Angiotensinogen and its cleaved derivatives inhibit angiogenesis. Hypertension. 2002;39(2):224-8. PubMed PMID: 11847188.

62. Nor JE, Mitra RS, Sutorik MM, Mooney DJ, Castle VP, Polverini PJ. Thrombospondin-1 induces endothelial cell apoptosis and inhibits angiogenesis by activating the caspase death pathway. J Vasc Res. 2000; 37(3):209-18. https://doi.org/10.1159/000025733. PubMed PMID: 10859480

63. Rehn M, Veikkola T, Kukk-Valdre E, Nakamura H, Ilmonen M, Lombardo C, et al. Interaction of endostatin with integrins implicated in angiogenesis. Proc Natl Acad Sci U S A. 2001;98(3):1024-9. https://doi.org/10.1073/pnas. 031564998. PubMed PMID: 11158588; PubMed Central PMCID: PMCPMC14702.

64. Yang X, Liaw L, Prudovsky I, Brooks PC, Vary C, Oxburgh L, et al. Fibroblast growth factor signaling in the vasculature. Curr Atheroscler Rep 2015;17(6): 509. https://doi.org/10.1007/s11883-015-0509-6. PubMed PMID: 25813213; PubMed Central PMCID: PMCPMC4593313.

65. Kim JY, Choi JS, Song SH, Im JE, Kim JM, Kim K, et al. Stem cell factor is a potent endothelial permeability factor. Arterioscler Thromb VasC Biol. 2014;34(7):1459-67. https://doi.org/10.1161/ATVBAHA.114.303575. PubMed PMID: 24790137

66. He T, Lu T, d'Uscio LV, Lam CF, Lee HC, Katusic ZS. Angiogenic function of prostacyclin biosynthesis in human endothelial progenitor cells. Circ Res. 2008;103(1):80-8. https://doi.org/10.1161/CIRCRESAHA.108.176057. PubMed PMID: 18511850; PubMed Central PMCID: PMCPMC2664088.
67. Foubert P, Silvestre JS, Souttou B, Barateau V, Martin C, Ebrahimian TG, et al. PSGL-1-mediated activation of EphB4 increases the proangiogenic potential of endothelial progenitor cells. J Clin Invest. 2007;117(6):1527-37. https://doi. org/10.1172/JCI28338. PubMed PMID: 17510705; PubMed Central PMCID: PMCPMC1866248

68. Kim YM, Kim KE, Koh GY, Ho YS, Lee KJ. Hydrogen peroxide produced by angiopoietin-1 mediates angiogenesis. Cancer Res. 2006;66(12):6167-74. https://doi.org/10.1158/0008-5472.CAN-05-3640. PubMed PMID: 16778190.

69. Chua CC, Hamdy RC, Chua BH. Upregulation of vascular endothelial growth factor by $\mathrm{H} 2 \mathrm{O} 2$ in rat heart endothelial cells. Free Radic Biol Med. 1998;25(8): 891-7. PubMed PMID: 9840733.

70. Scharner D, Rossig L, Carmona G, Chavakis E, Urbich C, Fischer A, et al. Caspase-8 is involved in neovascularization-promoting progenitor cell functions. Arterioscler Thromb Vasc Biol 2009;29(4):571-578. https://doi.org/ 10.1161/ATVBAHA.108.182006. PubMed PMID: 19122169.

71. Fuster JJ, Fernandez P, Gonzalez-Navarro H, Silvestre C, Nabah YN, Andres V. Control of cell proliferation in atherosclerosis: insights from animal models and human studies. Cardiovasc Res. 2010;86(2):254-64. https://doi.org/10. 1093/cvr/cvp363. PubMed PMID: 19900964.

72. Puhlmann M, Weinreich DM, Farma JM, Carroll NM, Turner EM, Alexander $H R$, Jr. Interleukin-1 beta induced vascular permeability is dependent on induction of endothelial tissue factor (TF) activity. J Transl Med 2005;3:37. https://doi.org/10.1186/1479-5876-3-37. PubMed PMID: 16197553; PubMed Central PMCID: PMCPMC1276820.

73. Wassmann S, Stumpf M, Strehlow K, Schmid A, Schieffer B, Bohm M, et al. Interleukin- 6 induces oxidative stress and endothelial dysfunction by overexpression of the angiotensin II type 1 receptor. Circ Res. 2004;94(4): 534-41. https://doi.org/10.1161/01.RES.0000115557.25127.8D. PubMed PMID: 14699015.

74. Furst R, Bubik MF, Bihari P, Mayer BA, Khandoga AG, Hoffmann F, et al. Atrial natriuretic peptide protects against histamine-induced endothelial barrier dysfunction in vivo. Mol Pharmacol. 2008;74(1):1-8. https://doi.org/10.1124/ mol.108.045773. PubMed PMID: 18413663.

75. Sigala F, Vourliotakis G, Georgopoulos S, Kavantzas N, Papalambros E, Agapitos $\mathrm{M}$, et al. Vascular endothelial cadherin expression in human carotid atherosclerotic plaque and its relationship with plaque morphology and clinical data. Eur J Vasc Endovasc Surg. 2003:26(5):523-8. PubMed PMID: 14532881.

76. Foster CA. VCAM-1/alpha 4-integrin adhesion pathway: therapeutic target for allergic inflammatory disorders. J Allergy Clin Immunol. 1996;98(6 Pt 2): S270-7. PubMed PMID: 8977536

\section{Ready to submit your research? Choose BMC and benefit from:}

- fast, convenient online submission

- thorough peer review by experienced researchers in your field

- rapid publication on acceptance

- support for research data, including large and complex data types

- gold Open Access which fosters wider collaboration and increased citations

- maximum visibility for your research: over $100 \mathrm{M}$ website views per year

At BMC, research is always in progress.

Learn more biomedcentral.com/submissions 